\begin{tabular}{l|l|l|l|l} 
JOURNAL OF PETROLOGY & VOLUME 40 & NUMBER 2 & PAGES 297-313 & 1999
\end{tabular}

\title{
Calculation of Peridotite Partial Melting from Thermodynamic Models of Minerals and Melts. II. Isobaric Variations in Melts near the Solidus and owing to Variable Source Composition
}

\author{
M. M. HIRSGHMANN ${ }^{1 *}$, M. S. GHIORSO ${ }^{2}$ AND E. M. STOLPER ${ }^{3}$ \\ 'DEPARTMENT OF GEOLOGY AND GEOPHYSICS, UNIVERSITY OF MINNESOTA, 310 PILLSBURY DRIVE S.E., MINNEAPOLIS, \\ MN 55455-0219, USA \\ ${ }^{2}$ DEPARTMENT OF GEOLOGICAL SGIENGES, AJ-20, UNIVERSITY OF WASHINGTON, SEATTLE, WA 98195, USA \\ ${ }^{3}$ DIVISION OF GEOLOGICAL AND PLANETARY SGIENCES, 170-25, CALTECH, PASADENA, CA 91125, USA
}

REGEIVED FEBRUARY 5, 1998; REVISED TYPESGRIPT AGGEPTED JUNE 26, 1998

We examine several issues related to peridotite partial melting by performing thermodynamic calculations using the MELTS algorithm. MELTS calculations suggest that the high alkali content of nearsolidus melts leads to their having high $\mathrm{SiO}_{2}$ contents at $1 \mathrm{GPa}$, but that near-solidus enrichments in $\mathrm{SiO}_{2}$ become less pronounced with increasing pressure, such that $2 \%$ partial melts at 3 GPa have only $\sim 1$ wt \% more $\mathrm{SiO}_{2}$ than higher melt fractions (5-15\%) at that pressure. Calculated near-solidus solid-liquid partitioning of $\mathrm{TiO}_{2}$ differs from that calculated and observed at high melt fraction, both at low and high pressure, reflecting variations in melt and mineral compositions as melting proceeds. Specifically, near the solidus, high liquid $\mathrm{SiO}_{2}$ and an abundant supply of charge coupling ions $\left(\mathrm{Na}^{+}\right.$, $A l^{3+}$ ) in clinopyroxene (cpx) makes Ti more compatible in the solid. We infer that similar effects are likely for other highly charged cations such as the high field strength elements (HFSE), U, and Th. To investigate the effects of heterogeneous source regions on major element chemistry of basaltic partial melts, we perform melting calculations for a range of peridotite compositions. For partial melts in equilibrium with spinel therzolite residues, $\mathrm{CaO} / \mathrm{Al}_{2} \mathrm{O}_{3}$ and $\mathrm{CaO}$ content increase with increasing temperature and decrease with increasing $\mathrm{Na}_{2} \mathrm{O}$ in the melt and $\mathrm{Al} / \mathrm{Cr}+\mathrm{Al})$ in coexisting spinel. Thus, at any given melt fraction, the $\mathrm{CaO} / \mathrm{Al}_{2} \mathrm{O}_{3}$ ratios and $\mathrm{CaO}$ contents of partial melts are inversely correlated with the fertility or enrichment of the source and only weakly dependent on the source $\mathrm{CaO} / \mathrm{Al}_{2} \mathrm{O}_{3}$ or $\mathrm{CaO}$ content. At fixed melt fraction, these effects of source depletion on melt composition ( $\mathrm{Na}_{2} \mathrm{O}$ decreases, $\mathrm{CaO} / \mathrm{Al}_{2} \mathrm{O}_{3}$ increases) are similar to the effects of increasing total extent of melting of a fixed source composition, and the two phenomena may therefore be difficult to discriminate on the basis of these melt variables alone. The effects of source variability on partial melting depend on whether compositionally distinct domains experience the same or different temperature-pressure paths. If they experience the same paths, as might be expected for small-scale heterogeneities, then enhanced melting of the enriched sources can yield partial melts with depleted characteristics such as low $\mathrm{Na}_{2} \mathrm{O}$ and high $\mathrm{CaO} / \mathrm{Al}_{2} \mathrm{O}_{3}$ relative to partial melts of depleted sources at the same pressure and temperature. The differing compatibility of $K$ and $\mathrm{Ti}$ in spinel peridotite minerals causes the $\mathrm{K}_{2} \mathrm{O} / \mathrm{Ti}_{2}$ ratio of partial melts to vary inversely with the total extent of melting (and with $\mathrm{Fe} \mathrm{O}^{*}$ ), so $\mathrm{K}_{2} \mathrm{O} / \mathrm{TiO}_{2}$ may not be a reliable indicator of source heterogeneity. Moreover, enriched high $\mathrm{K}_{2} \mathrm{O} / \mathrm{TiO}_{2}$ sources probably produce melts richer in $\mathrm{FeO}$ than depleted low $\mathrm{K}_{2} \mathrm{O} / \mathrm{TiO}_{2}$ sources at the same conditions. Consequently, the inverse correlation between regionally averaged $\mathrm{K}_{2} \mathrm{O} / \mathrm{TiO}_{2}$ and melt $\mathrm{FeO}$ * observed by Shen E Forsyth (1995, Journal of Geophysical Research 100, 2211-2237) is probably more strongly influenced by variations in extent of melting than by source heterogeneity.

KEY WORDS: mantle melting; peridotite; mantle composition; thermodynamic calculations 


\section{INTRODUGTION}

Variations in the major element composition of basaltic rocks are widely used as probes of partial melting processes in the mantle (e.g. Dick et al., 1984; Klein \& Langmuir, 1987; Niu \& Batiza, 1991; Kinzler \& Grove, 1992b; Langmuir et al., 1992). Accurate interpretation of mantle processes from basalt composition requires detailed understanding of the effects on melt composition of temperature, pressure, extent and style of melting, and source composition. In recent years, experimental studies have provided a wealth of constraints on the compositions of partial melts of peridotite (Kinzler \& Grove, 1992a; Hirose \& Kushiro, 1993; Baker \& Stolper, 1994; Walter \& Presnall, 1994; Baker et al., 1995; Longhi, 1995; Kushiro, 1996; Kinzler, 1997; Robinson et al., 1998). However, there remain a number of outstanding questions regarding the compositions of partial melts of the mantle. For example, despite years of experimental study, we have only recently obtained direct evidence for the compositions of near-solidus partial melts of fertile peridotite (Baker et al., 1995), and even now the character of such melts remains controversial (Walter et al., 1995; Baker et al., 1996; Falloon et al., 1996, 1997; Hirschmann et al., 1998a; Robinson et al., 1998). Additionally, available experimental data do not strongly constrain the quantitative effects of variations in source heterogeneity on the compositions of partial melts.

These problems can be partly addressed with increasingly accurate experiments, but we believe that experiments alone are not sufficient to resolve many important questions: forward models of mineral-melt equilibria are also required if we are to understand mantle melting more fully. Such models allow numerical experiments that, though not supplanting physical experiments, have the advantage of examining idealized melting phenomena in greater detail and with greater control over key variables (e.g. composition, pressure, temperature, melting process) than is generally possible in the laboratory. Such numerical simulations may be particularly useful under conditions that are intrinsically difficult in actual phase equilibrium experiments (such as very near the solidus or under adiabatic conditions) and can guide our intuition about complex phenomena. The MELTS algorithm (Ghiorso \& Sack, 1995) offers an internally consistent vehicle for understanding how source compositions (e.g. 'enrichment' or 'depletion' of source rocks) influence phase equilibria. Such an understanding could be arrived at by direct experiment only after comprehensive study examining the phase equilibria of a range of peridotitic compositions and, without the benefit of a thermodynamic treatment of the systematics, even such a study would be limited in quantifying or separating the complex interactions that collectively influence melting phenomena and how they might be manifested in the compositions of erupted basalts.
Hirschmann et al. (1998b) have shown that MELTS calculations capture the essential features of the phase equilibria of partially molten peridotite up to the lowest pressures of the garnet stability field. Although the calculations have inaccuracies, the extent of agreement is sufficient to allow numerical simulations of mantle melting processes that lead to useful insights that are not otherwise available. Methods for applying MELTS to peridotite partial melting problems and comparisons between MELTS calculations and peridotite partial melting experiments (especially at pressures near $1 \mathrm{GPa}$ ) have been given by Hirschmann et al. (1998b). In this paper, we use MELTS to address two key topics related to peridotite melting and their connection to basalt petrogenesis: (1) the geochemical character of near-solidus partial melts of peridotite; (2) the effect of peridotite heterogeneity on partial melt compositions. A companion paper in this series (Hirschmann et al., 1999) addresses variations and controls on two other variables affecting melt production in basalt source regions (the distribution of entropy among liquid and solid phases during melting and the amount of melt produced as a function of changing temperature at constant pressure; i.e. the 'isobaric productivity') and also discusses the effects of water on melt production. Also, a subsequent paper (Asimow et al., 1999) will address the effects of polybaric melting on aggregated melt compositions. Because of imperfections in MELTS, the treatments are not in all cases definitive, but the exercises illustrate the potential of this approach to improve our understanding of important issues and processes in mantle petrology.

The first issue dealt with in this paper is the nature of very low degree partial melts of peridotite. The character of such near-solidus partial melts is thought to be of great importance in determining the geochemical and geodynamical behavior of partially melting mantle (McKenzie, 1985a, 1985b). In particular, if the melting process approaches fractional fusion in all or part of pressure-release melting beneath ridges (Salters \& Hart, 1989; Johnson et al., 1990; Kinzler \& Grove, 1992b; Langmuir et al., 1992; Iwamori et al., 1995; Spiegelman, 1996; Kelemen et al., 1997), all or most liquids produced during mantle melting correspond to low degree or nearsolidus melts of continuously changing peridotite bulk compositions. Despite the importance of liquids produced by low degrees of melting of peridotite, there are few experiments that directly constrain melting under these conditions. One such study, by Baker et al. (1995), presented data on the compositions of partial melts of a fertile peridotite at $1 \mathrm{GPa}$ at melt fractions down to $2 \%$; the results were unexpected and have as a consequence engendered considerable debate (Walter et al., 1995; Baker et al., 1996; Falloon et al., 1996). MELTS calculations provide a powerful way to evaluate the controversial results of Baker et al. (1995) and to explore the 
likely properties of near-solidus melts for a wide range of conditions and peridotite bulk compositions.

The second set of issues addressed in this paper relates to the influence of source heterogeneity on the chemical compositions of partial melts of the mantle. There is substantial evidence from isotopes and trace elements that the source regions of major basalt types (e.g. oceanic island basalt, OIB; mid-ocean ridge basalt, MORB; continental basalt) are heterogeneous on both regional and local scales (Dupré \& Allègre, 1983; Stille et al., 1986; Zindler \& Hart, 1986; Prinzhofer et al., 1989; Langmuir et al., 1992), but the extent of major element variation in these sources is less well established. For example, it has been suggested that major element source heterogeneity plays a primary role in the observed compositional variability of MORB (Natland, 1989; Shen \& Forsyth, 1995), but others have argued that mantle heterogeneity is only of secondary importance in MORB petrogenesis (Langmuir et al., 1992). Also, arguments about melting processes have been constructed based on the assumption that source heterogeneity affects some major element characteristics more than others (Niu \& Hékinian, 1997). In fact, relatively little is known about the effect of the peridotite bulk composition on extent of melting or melt composition, as experimental data on the effects of source depletion and enrichment on peridotite phase equilibria remain sparse. Some empirical parameterizations can be used to predict the effects of variable source composition (Kinzler \& Grove, 1992b; Langmuir et al., 1992), but even these models have limited capacity to account for compositionally variable partition coefficients or modal variations in residual mineralogy, and they contain little or no information on variations in melt productivity with source composition or degree of melting. In contrast, thermodynamic calculations are well suited to exploring the effects of variable source composition on peridotite melting behavior.

\section{NEAR-SOLIDUS MELTING OF PERIDOTITE}

The experiments of Baker et al. (1995) suggested that near-solidus partial melts of fertile peridotite at $1 \mathrm{GPa}$ differ from melts formed at higher melt fraction in a number of important ways. For example, the near-solidus melts had higher $\mathrm{SiO}_{2}$ than melts produced at higher degrees of melting, and the partitioning of $\mathrm{Ti}$ (and by inference other highly charged cations) depended strongly on the extent of melting. Also, the normative diopside $[12 \%$; see corrected analyses by Hirschmann et al. $(1998 b)$ - note that this is more normative diopside than that suggested by the original Baker et al. (1995) analyses] was lower than previously reported for nominally anhydrous partial melts of peridotite (Stolper, 1980; Falloon
Table 1: Peridotite compositions used for calculations

\begin{tabular}{|c|c|c|c|c|}
\hline & $\mathrm{DMM}^{1}{ }^{1}$ & $\mathrm{MM}^{2}$ & LOSIMG $^{3}$ & $R 123^{4}$ \\
\hline $\mathrm{SiO}_{2}$ & 44.65 & $45 \cdot 47$ & $45 \cdot 96$ & $45 \cdot 23$ \\
\hline $\mathrm{TiO}_{2}$ & 0.04 & 0.11 & 0.18 & 0.27 \\
\hline $\mathrm{Al}_{2} \mathrm{O}_{3}$ & 2.37 & 4.00 & 4.06 & 4.80 \\
\hline $\mathrm{Cr}_{2} \mathrm{O}_{3}$ & 0.40 & 0.68 & 0.47 & 0.31 \\
\hline $\mathrm{FeO} *$ & $8 \cdot 15$ & $7 \cdot 22$ & 7.54 & 8.73 \\
\hline $\mathrm{MgO}$ & $42 \cdot 14$ & 38.53 & 37.78 & 35.51 \\
\hline $\mathrm{CaO}$ & $2 \cdot 14$ & 3.59 & $3 \cdot 21$ & 4.04 \\
\hline $\mathrm{Na}_{2} \mathrm{O}$ & 0.06 & 0.31 & 0.33 & 0.45 \\
\hline Sum & 99.95 & 99.91 & 99.53 & $99 \cdot 36$ \\
\hline mg-no. & $90 \cdot 20$ & $90 \cdot 48$ & 89.92 & 87.87 \\
\hline
\end{tabular}

${ }^{1}$ Wasylenki et al. (1996). ${ }^{2}$ Baker \& Stolper (1994). ${ }^{3}$ Hart \& Zindler (1986). ${ }^{4}$ Frey et al. (1985).

\& Green, 1987; Hirose \& Kushiro, 1993), and the olivineliquid $\mathrm{Fe}-\mathrm{Mg}$ distribution coefficient was lower than the usually expected value of $0.30 \pm 0.03$ (Baker et al., 1996; Falloon et al., 1996). These observations were unexpected based on results of earlier, higher-melt-fraction experiments and were not predicted by previous parameterizations of mantle melting. Here we use MELTS to explore the underlying thermodynamic basis for the near-solidus behavior reported by Baker et al. and to predict how these effects may change with varying bulk composition and pressure.

\section{$\mathrm{SiO}_{2}$ concentrations of near-solidus liquids}

As shown by Baker et al. (1995) and Hirschmann et al. (1998b), MELTS calculations suggest that near-solidus $(<5 \%$ melting) partial melts of a fertile spinel peridotite (MM3; composition given in Table 1) at 1 GPa are silica rich relative to higher-degree partial melts of the same bulk composition (Fig. 1). Although as described by Hirschmann et al. (1998b) the magnitude of the calculated effect is probably exaggerated because the MELTScalculated alkali contents of partial melts of peridotite are systematically high, the fact that the experiments and the completely independent MELTS calculations produce similar trends in silica content with degree of melting is a strong indication that this newly discovered phenomenon is not an experimental artifact. In contrast, MELTS calculations for a depleted peridotite that lacks appreciable alkalis (DMM1, Table 1) do not predict a pronounced increase in silica unless melt fraction is less than $\sim 1 \%$ (Hirschmann et al., 1998b), and this is supported by experimental results at 1-1.5 GPa on depleted peridotite compositions (Wasylenki et al., 1996; Robinson 
\begin{tabular}{l|l|l|l} 
JOURNAL OF PETROLOGY & VOLUME 40 & NUMBER 2 & FEBRUARY 1999
\end{tabular}

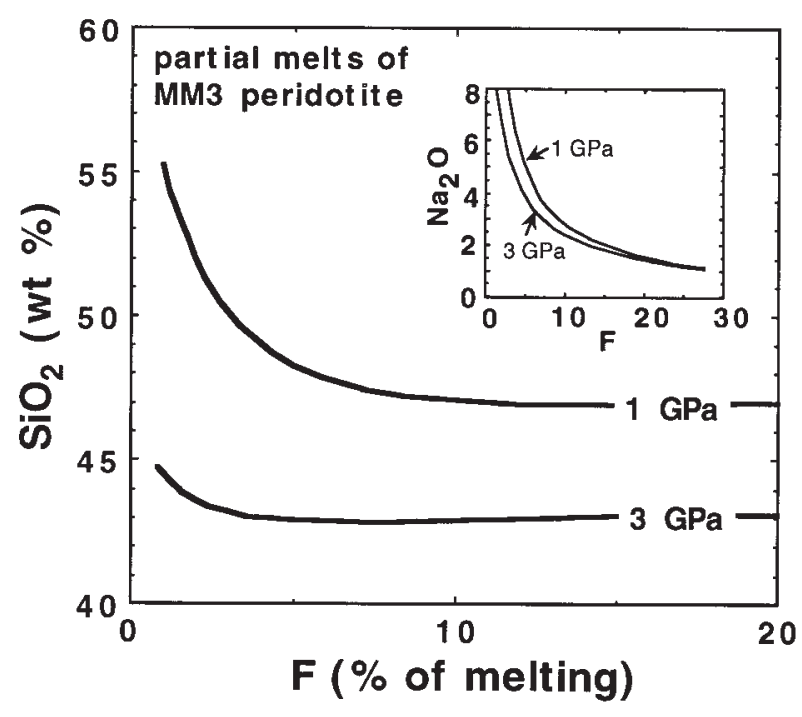

Fig. 1. Calculated wt $\% \mathrm{SiO}_{2}$ of partial melts of MM3 peridotite (Baker \& Stolper, 1994) vs melt fraction $(F$, in wt \%) at 1 and $3 \mathrm{GPa}$. It should be noted that at low melt fraction $\mathrm{SiO}_{2}$ increases sharply at $1 \mathrm{GPa}$ but not at $3 \mathrm{GPa}$. Inset shows $\mathrm{Na}_{2} \mathrm{O}$ in calculated partial melts of MM3 at 1 and $3 \mathrm{GPa}$.

et al., 1998). We note in passing that Robinson et al. (1998) compared the results of their experiments with MELTS calculations. Because the comparison was made as a function of temperature, there appear to be rather strong disagreements, but these are caused by welldocumented systematic discrepancies between temperature and melt fraction (Hirschmann et al., 1998b). When the experiments of Robinson et al. (1998) are compared with MELTS calculations as a function of melt fraction, calculations and experiment are in much closer agreement. MELTS calculations and experiments thus suggest that, at least near $1 \mathrm{GPa}$, strong enrichments in alkalis cause liquids in equilibrium with lherzolitic assemblages to be silica rich. Indeed, as shown by Hirschmann et al. (1998a), a large body of experimental data supports this hypothesis.

The effect of alkalis on the silica content of liquids in equilibrium with a lherzolitic mineral assemblage can be understood in terms of the activity of silica, $a_{\mathrm{SiO}_{2}}^{\text {liqu }}$, which is buffered by equilibrium between liquid, olivine (ol), and orthopyroxene (opx) through the reaction

$$
\underset{\text { olivine liquid }}{\mathrm{Mg}_{2} \mathrm{SiO}_{4}}+\underset{\text { orthopyroxene }}{\mathrm{SiO}_{2}} \rightleftharpoons \underset{\mathrm{Mg}_{2} \mathrm{SiO}_{6}}{\rightleftharpoons}
$$

During small and moderate degrees of mantle melting, variations in ol and opx compositions are small, as are the effects of temperature on this equilibrium. Therefore, as partial melting of lherzolite progresses at fixed pressure,

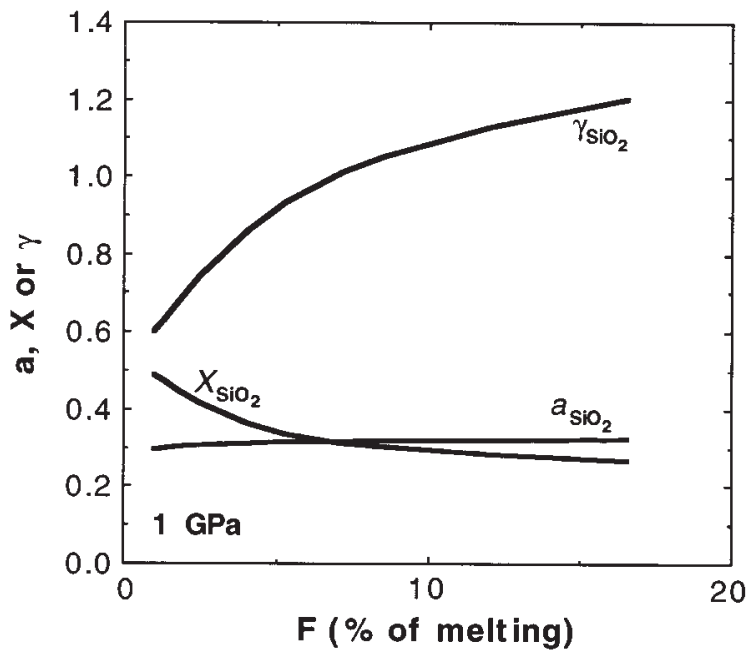

Fig. 2. Calculated activity $\left(a_{\mathrm{SiO}_{2}}\right)$, activity coefficient $\left(\gamma_{\mathrm{SiO}_{2}}\right)$ and mole fraction $\left(X_{\mathrm{SiO}_{2}}\right)$ of silica in partial melt of MM3 fertile peridotite at 1 GPa vs melt fraction. The activity is buffered by coexistence of olivine and opx, but the activity coefficient changes significantly as the solidus is approached, owing primarily to increasing $\mathrm{Na}$ in the liquid. Hence, the mole fraction of silica in the melt increases near the solidus.

the activity of silica is nearly constant, even though liquid composition varies considerably. This is well illustrated by MELTS calculations of melting of MM3 peridotite at $1 \mathrm{GPa}$ (Figs 1 and 2). However, because $a_{\mathrm{SiO}_{2}}^{\text {liquid }}$ is buffered during lherzolite partial melting, any changes in melt composition must follow a path such that changes in liquid silica mole fraction $X_{\mathrm{SiO}_{2}}^{\text {liquid }}$ are accompanied by compensating changes in the activity coefficient of silica $\gamma_{\mathrm{SiO}_{2}}^{\text {liquid }}$. Conversely, changes in liquid composition that affect $\gamma_{\mathrm{SiO}_{2}}^{\text {liquid }}$ must be accompanied by compensating changes in liquid silica mole fraction. Thus, as shown in Fig. 2, MELTS calculations indicate that at $1 \mathrm{GPa}$, $\gamma_{\mathrm{SiO}_{2}}^{\text {liquid }}$ is significantly lower in alkali-rich near-solidus partial melts than it is at higher melt fractions, but because $\gamma_{\mathrm{SiO}_{2}}^{\text {liquid }}$ is nearly constant, low $\gamma_{\mathrm{SiO}_{2}}^{\text {liquid }}$ at the low melt fractions is accompanied by higher $X_{\mathrm{SiO}_{2}}^{\text {liquid }}$.

The low values of $\gamma_{\mathrm{SiO}_{2}}^{\text {liquid }}$ predicted by MELTS for nearsolidus melts reflect the high alkali concentrations of these liquids (a consequence of the incompatibility of $\mathrm{Na}$ under these conditions) and the large negative enthalpy of mixing between $\mathrm{Na}_{2} \mathrm{SiO}_{3}$ and $\mathrm{SiO}_{2}$ in the silicate liquid model of Ghiorso \& Sack (1995). As reviewed by Hirschmann et al. (1998a), this is consistent with calorimetric and phase equilibria data in simple synthetic silicate melts at low pressure (Kushiro, 1975; Ryerson, 1985; Hess, 1995; Navrotsky, 1995).

In most basalt source regions, initial melting of fertile peridotite is thought to occur at pressures much greater than 1 GPa (Salters \& Hart, 1989; Langmuir et al., 1992; Hirschmann \& Stolper, 1996). Thus, it is important to establish whether the unusual silica contents documented 
by experiments and predicted by MELTS at 1 GPa persist near the fertile peridotite solidus at higher pressures. At $3 \mathrm{GPa}$, calculated partial melts of MM3 peridotite also show increased $\mathrm{SiO}_{2}$ near the solidus (Fig. 1), but the magnitude of the effect is greatly reduced from that calculated at $1 \mathrm{GPa}$; e.g. whereas at $1 \mathrm{GPa}$, a $2 \%$ partial melt is predicted to have $5 \mathrm{wt} \%$ more $\mathrm{SiO}_{2}$ than a $10 \%$ partial melt, at $3 \mathrm{GPa}$ the predicted enrichment is only 0.7 wt $\%$.

As pressure increases, the jadeite component of cpx is stabilized, leading to larger values of $D_{\mathrm{Na}}^{\mathrm{cpx} / \mathrm{liq}}$ (Blundy et al., 1995). As a consequence, $\mathrm{Na}$ is less enriched in lowdegree melts at $3 \mathrm{GPa}$ than at $1 \mathrm{GPa}$, so at high pressure its effect on $\gamma_{\mathrm{SiO}_{2}}^{\text {liquid }}$ is less pronounced at a given melt fraction than at low pressure. However, despite the increasing compatibility of $\mathrm{Na}$ at higher pressure (underestimated by MELTS, which predicts an increase in $D_{\mathrm{Na}}^{\text {cpx/liq }}$ of $50 \%$ from $1 \mathrm{GPa}$ to $3 \mathrm{GPa}$, approximately half the increase implied by most experimental determinations; Blundy et al., 1995), calculated $\mathrm{Na}_{2} \mathrm{O}$ is still highly enriched in near-solidus liquids at both $1 \mathrm{GPa}$ and $3 \mathrm{GPa}$ (Inset to Fig. 1); consequently, we conclude that the change in Na partitioning is insufficient to explain the predicted pressure-dependent behavior of $\mathrm{SiO}_{2}$ near the solidus. An additional factor in the significantly diminished near-solidus $\mathrm{SiO}_{2}$ enrichment at $3 \mathrm{GPa}$ is that the intrinsic effect of alkalis on the $\mathrm{SiO}_{2}$ contents of $(\mathrm{ol}+\mathrm{opx})$-saturated melts decreases with increasing pressure (Hirschmann et al., 1998a). In other words, with increasing pressure, alkalis have a diminished effect on the $\gamma_{\mathrm{SiO}_{2}}^{\text {liquid }}$ of $(\mathrm{ol}+\mathrm{opx})$-saturated liquids. As depicted in Fig. 3, available data on melting of natural peridotites and related compositions show that

$$
\left(\frac{\partial X_{\mathrm{SiO}_{2}}}{\partial X_{\mathrm{Alk}}}\right)_{\mathrm{P}}^{\text {cotectic }},
$$

the change in mole fraction of $\mathrm{SiO}_{2}$ in liquids saturated in ol + opx \pm cpx \pm spinel \pm garnet \pm plagioclase per increment of alkalis added at fixed pressure, is strongly positive at low and moderate pressures, but decreases as pressure increases. MELTS calculations on the MM3 composition also show a significant decrease in

$$
\left(\frac{\partial X_{\mathrm{SiO}_{2}}}{\partial X_{\mathrm{Alk}}}\right)_{\mathrm{P}}^{\text {cotectic }},
$$

with increasing pressure (continuous curve in Fig. 3), although the magnitude of the effect predicted by MELTS is lower than that observed by experiment, particularly at lower pressures.

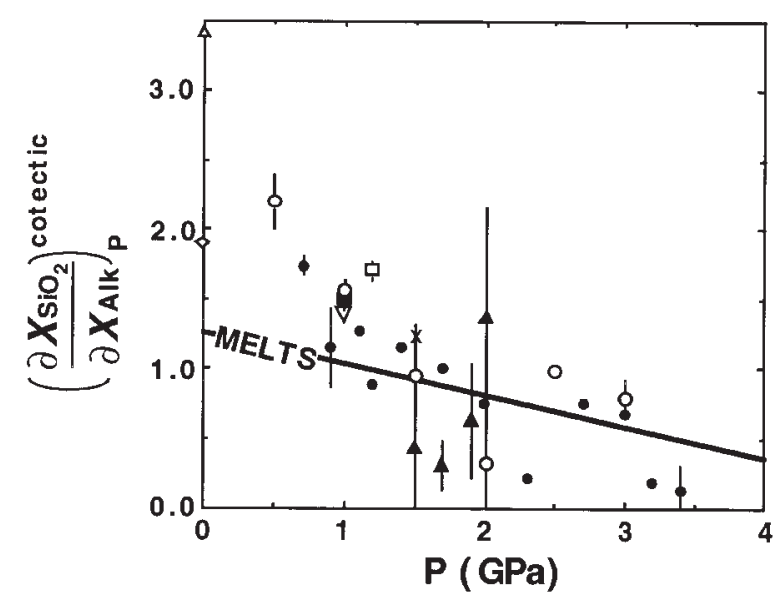

Fig. 3. The effect of alkalis on the mole fraction of $\mathrm{SiO}_{2}$ in liquids saturated with ol + opx \pm cpx \pm sp \pm plag \pm gt at constant pressure, expressed as

$$
\left(\frac{\partial X_{\mathrm{SiO}_{2}}}{\partial X_{\mathrm{Alk}}}\right)_{\mathrm{P}}^{\text {cotectic }} \text {. }
$$

The continuous curve is from MELTS calculations on fertile MM3 peridotite at pressures between $0 \cdot 25$ and $3 \mathrm{GPa}$. Experimental data include: partial melting experiments on peridotite compositions MM3 (ם; Baker \& Stolper, 1994; Baker et al., 1995) and PHN-1611 (O; Kushiro, 1996); experiments on NCMAS [O; Walter \& Presnall, 1994; with Na-free data at 2.3, 3.2 and 3.4 GPa from Gudfinnsson \& Presnall (1996)] and NCMFAS model peridotites (inverted triangle; Soulard \& Wood, 1994); the 1.2 $\mathrm{GPa}_{2} \mathrm{O}_{5}$-free experiments of Kinzler \& Grove (1992a; $\square$ ); the 1.5 GPa fertile peridotite near-solidus determinations $(x)$ of Robinson et al. (1998); and data from the systems $\mathrm{Na}_{2} \mathrm{O}$ $\mathrm{MgO}-\mathrm{SiO}_{2}$ (diamond; NMS) and $\mathrm{K}_{2} \mathrm{O}-\mathrm{MgO}-\mathrm{SiO}_{2}(\triangle$; KMS) (Roedder, 1951; Schairer et al., 1954). Also plotted are slopes extracted from liquids saturated in ol $+\mathrm{opx}+\mathrm{cpx}+\mathrm{sp}$ at $1.5,1 \cdot 7$, and $1.9 \mathrm{GPa}$ from $\operatorname{Kinzler}(1997 ; \boldsymbol{\Delta})$. Error bars are $1 \sigma$ errors from linear regression of $\mathrm{SiO}_{2}$ vs alkali trends. [See Hirschmann et al. (1998a) for details of sources and interpretation of experimental data.]

\section{$\mathrm{TiO}_{2}$ and trace element partitioning near the peridotite solidus}

One of the most interesting aspects of the low-degree melts documented by Baker et al. (1995) is the observed behavior of $\mathrm{TiO}_{2}$ near the solidus. $\mathrm{TiO}_{2}$ behaves incompatibly in the residual mantle assemblage, so it had been expected that liquids formed at low melt fraction would have the highest $\mathrm{TiO}_{2}$ content (e.g. Kinzler \& Grove, 1992a; Langmuir et al., 1992). Instead, the experiments show that $\mathrm{TiO}_{2}$ goes through a maximum at $\sim 10 \%$ melting. MELTS predicts similar results both at $1 \mathrm{GPa}$ and $3 \mathrm{GPa}$ (Fig. 4a), though the predicted nearsolidus decrease is less pronounced at higher pressure. The smaller concentrations of $\mathrm{TiO}_{2}$ in melts near the solidus (relative to higher melt fraction) in both experiments and calculations can be traced in part to the increased modal abundance of cpx near the solidus. As cpx is the chief solid host of $\mathrm{TiO}_{2}$ in the peridotite mineral assemblage, all other things being equal, increased modal 


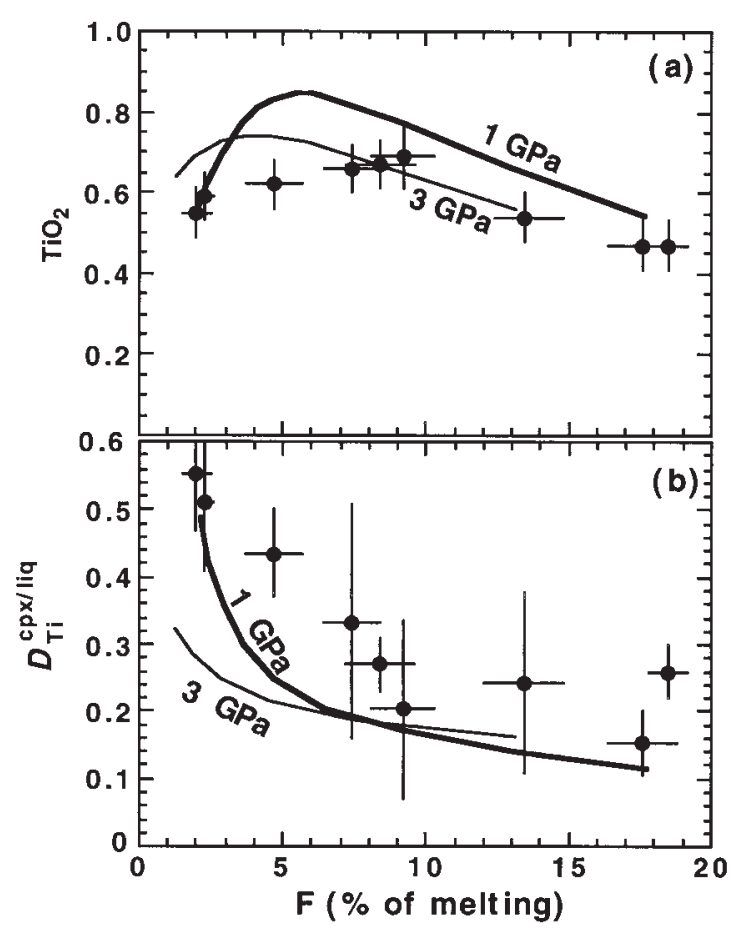

Fig. 4. (a) $\mathrm{TiO}_{2}$ in silicate liquids for the MM3 partial melting experiments of Baker \& Stolper (1994) and Baker et al. (1995) compared with MELTS calculations for MM3 peridotite. The increase in $D_{\mathrm{Ti}}^{\mathrm{cpx} / \mathrm{liq}}$ and in modal cpx in the residue near the solidus actually causes $\mathrm{TiO}_{2}$ to decrease as the solidus is approached, despite the overal incompatible behavior of $\mathrm{Ti}$ in spinel peridotite residual minerals. (b) Partition coefficient for Ti between $\mathrm{cpx}$ and silicate liquid $\left(D_{\mathrm{Ti}}^{\mathrm{cp} / \mathrm{liq}}\right)$ at 1 GPa for MM3 experiments (Baker \& Stolper, 1994; Baker et al., 1995) compared with MELTS calculations at $1 \mathrm{GPa}$ and $3 \mathrm{GPa}$.

cpx causes increases in the bulk partition coefficient (Klein \& Langmuir, 1987; Niu \& Batiza, 1994). However, an additional influence on $\mathrm{Ti}$ in the liquid is the marked increase in $D_{\mathrm{Ti}}^{\mathrm{cps} / \mathrm{melt}}$ as the solidus is approached, as indicated both by calculations and experiments (Fig. 4b). As detailed in the following paragraphs, the increase in $D_{\mathrm{Ti}}^{\mathrm{cpx} / \mathrm{melt}}$ near the peridotite solidus is traceable to compositionally dependent activity coefficients for Ti-bearing components in both silicate liquid and cpx.

Part of the variation in $D_{\mathrm{Ti}}^{\mathrm{cpx} / \text { melt }}$ is related to changes in the composition of the liquid. In the MELTS calculation at $1 \mathrm{GPa}, D_{\mathrm{Ti}}^{\text {cpx }} /$ melt increases from 0.114 at $F=$ $18 \%$ to 0.489 at $F=2 \%$ (Fig. 4 b), where $F$ is the mass fraction of melt present. Over this same interval, changes in liquid composition cause the MELTS-calculated activity coefficient of $\mathrm{TiO}_{2}, \gamma_{\mathrm{TiO}_{2}}^{\text {liquid }}$, to increase from 1.06 to 3·12. Because $D_{\mathrm{Ti}}^{\mathrm{cpx} / \mathrm{melt}}$ varies linearly with $\gamma_{\mathrm{TiO}_{2}}^{\text {liquid }}$ [see equation (13) of Hirschmann \& Ghiorso (1994)], it follows that about $3 / 4$ of the calculated change in $D_{\mathrm{Ti}}^{\mathrm{cpx} / \text { melt }}$ at 1 GPa reflects changes in liquid composition as the solidus is approached. However, this cannot be the only cause of predicted increases in $D_{\mathrm{Ti}}^{\text {cpx }}$ /melt near the solidus because at $3 \mathrm{GPa}$ the MELTS-calculated $D_{\mathrm{Ti}}^{\mathrm{cp} / \mathrm{melt}}$ is about a factor of two greater at $2 \%$ melting than at cpx exhaustion ( 18\% melting; Fig. 4b), even though there is little change in calculated $\gamma_{\mathrm{TiO}_{2}}^{\text {liquid }}$ as a function of melt fraction (e.g. at $2 \%$ melting, $\gamma_{\mathrm{TiO}_{2}}^{\text {melt }}$ is calculated to be 1.54 ; near cpx exhaustion, it is 1.55$)$.

What is responsible for the dramatic increase in calculated $\gamma_{\mathrm{TiO}_{2}}^{\text {liquid }}$ in near-solidus melts at low pressure, and why is a similar increase not evident in the calculations at higher pressure? An important factor is the wellestablished positive correlation between a liquid's silica content and its $\gamma_{\mathrm{TiO}_{2}}^{\text {liquid }}$ (Kushiro, 1975; Watson, 1976; Ryerson, 1978, 1985; Ryerson \& Watson, 1987; Hess, 1995). On the other hand, this effect is offset to some extent by the increase in alkali contents of near-solidus liquids; i.e. alkalis reduce $\gamma_{\mathrm{TiO}_{2}}^{\text {liquid }}$ in silicate liquids by forming complexes with $\mathrm{TiO}_{2}$ in which the $\mathrm{Ti}^{4+}$ ions take on a variety of coordination states (Dickinson \& Hess, 1985; Lange \& Carmichael, 1987; Lange \& Navrotsky, 1993; Mysen \& Neuville, 1995). Assuming that the silica and alkali content are the most significant factors in variations in $\gamma_{\mathrm{TiO}_{2}}^{\text {liquid }}$, we suggest that at $1 \mathrm{GPa}$, where the increase in silica as the solidus is approached is large, the net effect is an increase in $\gamma_{\mathrm{TiO}_{2}}^{\text {liquid }}$, whereas at $3 \mathrm{GPa}$, where the change in silica near the solidus is small, the competing effects of increased $\mathrm{SiO}_{2}$ and $\mathrm{Na}_{2} \mathrm{O}$ nearly cancel.

Although as explained in the previous paragraphs, changes in liquid composition (and therefore in $\gamma_{\mathrm{TiO}_{2}}^{\text {liquid }}$ ) can account for most of the observed (and MELTS-calculated) near-solidus change in $D_{\mathrm{Ti}}^{\mathrm{cpx} / \mathrm{melt}}$ at $1 \mathrm{GPa}$, the MELTS calculations indicate that such changes do not account for all of it and that they cannot account for any of the predicted change in $D_{\mathrm{Ti}}^{\text {cpx }}$ /melt at $3 \mathrm{GPa}$. An additional important factor is the change in cpx composition near the solidus: $\mathrm{Ti}^{4+}$ enters cpx via charge coupled substitutions involving $\mathrm{Al}^{3+}, \mathrm{Fe}^{3+}$, and $\mathrm{Na}^{+}$(Sack et al., 1987; Gallahan \& Nielsen, 1992). As the degree of melting increases, the concentrations of these elements in cpx decrease significantly because they are incompatible. The net result is that $\mathrm{TiO}_{2}$ is more compatible near the solidus, where there are abundant charge-coupling components available in the cpx, and less compatible after significant extents of melting have taken place. The effect of changing cpx compositions (and changing cpx mode) is more important at $3 \mathrm{GPa}$, where near-solidus cpx contains more $\mathrm{Al}^{3+}$ and $\mathrm{Na}^{+}$(Blundy et al., 1995; Putirka et al., 1996) than at $1 \mathrm{GPa}$. This change in cpx composition with increased melting explains why there is still a significant shift in $D_{\mathrm{Ti}}^{\mathrm{cps} / \mathrm{melt}}$ predicted by MELTS near the solidus at $3 \mathrm{GPa}$ even though $\gamma_{\mathrm{TiO}_{2}}^{\text {liquid }}$ is essentially unchanged. It should be noted that the effects of changing cpx composition will be enhanced during fractional melting, as the composition of residual cpx changes more per increment of melting in this case. 
Variability of $\mathrm{Ti}$ partitioning near the solidus has, by analogy, implications for the behavior of other geochemically important, highly charged cations such as $\mathrm{U}^{4+}, \mathrm{Th}^{4+}, \mathrm{Pa}^{5+}$, $\mathrm{Nb}^{5+}, \mathrm{Ta}^{5+}, \mathrm{Zr}^{4+}, \mathrm{Hf}^{4+}$, and rare earth elements (REE). As for $\mathrm{Ti}^{4+}$, the primary host for these elements in the shallow mantle is cpx (at higher pressure, garnet may also be significant) and the substitution of these elements into cpx is also controlled by coupled substitutions with monovalent and trivalent cations. Therefore, the compatibility of these elements in peridotitic residues will also be controlled in part by the availability of chargebalancing $\mathrm{Na}^{+}, \mathrm{Fe}^{3+}$ and $\mathrm{Al}^{3+}$, and if the behavior of Ti is representative, the resultant variations in partitioning behavior can be substantial. Also, the behavior of these elements in silicate liquids may be affected in ways similar to that of $\mathrm{TiO}_{2}$; i.e. their activity coefficients in the liquid also vary with such factors as liquid silica and alkali content, as suggested by two-liquid partitioning experiments (Watson, 1976; Ryerson, 1978). Recent experiments confirm that the partitioning of these elements with respect to cpx does vary significantly with the $\mathrm{Na}$ and $\mathrm{Al}^{3+}$ concentrations of pyroxene and therefore with pressure (Forsythe et al., 1994; Lundstrom et al., 1994; Salters \& Longhi, 1996).

In summary, nearer the solidus and at higher pressure, where pyroxenes are richer in $\mathrm{Na}^{+}$and $\mathrm{Al}^{3+}$, highly charged cations (e.g. $\mathrm{U}^{4+}, \mathrm{Th}^{4+}, \mathrm{Pa}^{5+}, \mathrm{Nb}^{5+}, \mathrm{Ta}^{5+}, \mathrm{Zr}^{4+}, \mathrm{Hf}^{4+}$, $\mathrm{REE}$ ) will generally be more compatible, as we have observed and calculated for $\mathrm{Ti}^{4+}$. Given the considerable importance of the behavior of these incompatible elements in understanding petrogenesis and the limitation of significant fractionations between them to processes occurring at low melt fraction, the anticipated variations in their near-solidus partitioning behavior could have significant impact on petrogenetic modeling; one example of this (interpretation of variations in $\mathrm{K} / \mathrm{Ti}$ in basalts) is examined in more detail below. As for $\mathrm{Ti}$, however, changes in liquid composition near the solidus can also have complex (and competing) effects on trace element partitioning, and these are likely to be difficult to anticipate quantitatively without more information or more sophisticated thermodynamic models of liquid and pyroxene. It should be noted, finally, that more fertile source compositions are richer in $\mathrm{Na}, \mathrm{Fe}^{3+}$, and $\mathrm{Al}$, so $\mathrm{Ti}$ and other highly charged elements are predicted to be more compatible near the solidus for such compositions, adding yet another possible dimension to the variability of trace element partitioning during mantle melting.

\section{EFFEGTS OF SOURGE REGION HETEROGENEITY}

To explore some of the effects of variable peridotite composition on the compositions of partial melts, we have calculated the isobaric melting behavior of four peridotite compositions. These include the MM3 and DMM1 compositions discussed by Hirschmann et al. (1998b) and two additional compositions, LOSIMG and R123 (Table 1). LOSIMG is a model peridotite that is a plausible approximation of the bulk composition of the upper mantle (Hart \& Zindler, 1986), and R123 is a peridotite from the Ronda Massif (Frey et al., 1985). LOSIMG is close in composition to MM3, but differs in that its $m g$-number, $\mathrm{CaO} / \mathrm{Al}_{2} \mathrm{O}_{3}$, and $\mathrm{Cr}_{2} \mathrm{O}_{3}$ are slightly lower. $\mathrm{R} 123$ is rich in $\mathrm{Na}_{2} \mathrm{O}(0 \cdot 45 \%)$ and has a low $m g$ number $(87.9)$ and high modal cpx. These peridotite compositions are compared in Fig. 5 with the compilation of peridotite compositions of Herzberg et al. (1988). Although Fig. 5 shows that the range of natural peridotite compositions is very large, in general we can distinguish peridotites that are more 'enriched' from those that are more 'depleted', with the former being richer in $\mathrm{Na}_{2} \mathrm{O}$, lower in $m g$-number, and poorer in $\mathrm{Al}_{2} \mathrm{O}_{3}$ and $\mathrm{CaO}$ (and therefore having less modal cpx). Thus, R123 is 'enriched', DMM1 is 'depleted', and MM3 and LOSIMG are intermediate, or 'fertile', peridotites. Variations in $m g$ number between these four compositions are somewhat atypical (i.e. the depleted peridotite composition has an $m g$-number comparable with the fertile compositions), and this must be kept in mind as we try to interpret certain differences in their melting behavior.

\section{$\mathrm{Na}_{2} \mathrm{O}$ contents of partial melts vs melt fraction}

One of the difficulties in determining whether heterogeneous source compositions play a role in producing observed variations in the major element compositions of basalts is that there are few criteria that can in practice differentiate the effects of variable source composition from those of variations in extent of melting. Development of such criteria is partially impeded by the fact that source composition feeds back into the extent of melting (at a particular pressure and temperature), making it hard to separate the effects of these variables. These difficulties are well illustrated by $\mathrm{Na}_{2} \mathrm{O}$, which is commonly used as an indicator of the degree of melting by which a basalt was generated (e.g. Dick et al., 1984; Klein \& Langmuir, 1987). At any fixed melt fraction, peridotite sources with higher $\mathrm{Na}_{2} \mathrm{O}$ concentrations will produce partial melts richer in $\mathrm{Na}_{2} \mathrm{O}$. However, at any given temperature and pressure, an $\mathrm{Na}_{2} \mathrm{O}$-rich peridotite will generally melt to a greater extent than an $\mathrm{Na}_{2} \mathrm{O}$-poor one, thereby diluting the $\mathrm{Na}_{2} \mathrm{O}$ of resulting melt. If, as is generally the case, increased $\mathrm{Na}$ in the source is accompanied by other compositional variations that also tend to increase melt fraction (e.g. decreased $m g$-number, increased $\mathrm{K}_{2} \mathrm{O}, \mathrm{H}_{2} \mathrm{O}, \mathrm{CO}_{2}$, etc.), the dilution of $\mathrm{Na}$ owing to increased melt fraction will be even greater. Thus, 
\begin{tabular}{l|l|l|l} 
JOURNAL OF PETROLOGY & VOLUME 40 & NUMBER 2 & FEBRUARY 1999
\end{tabular}
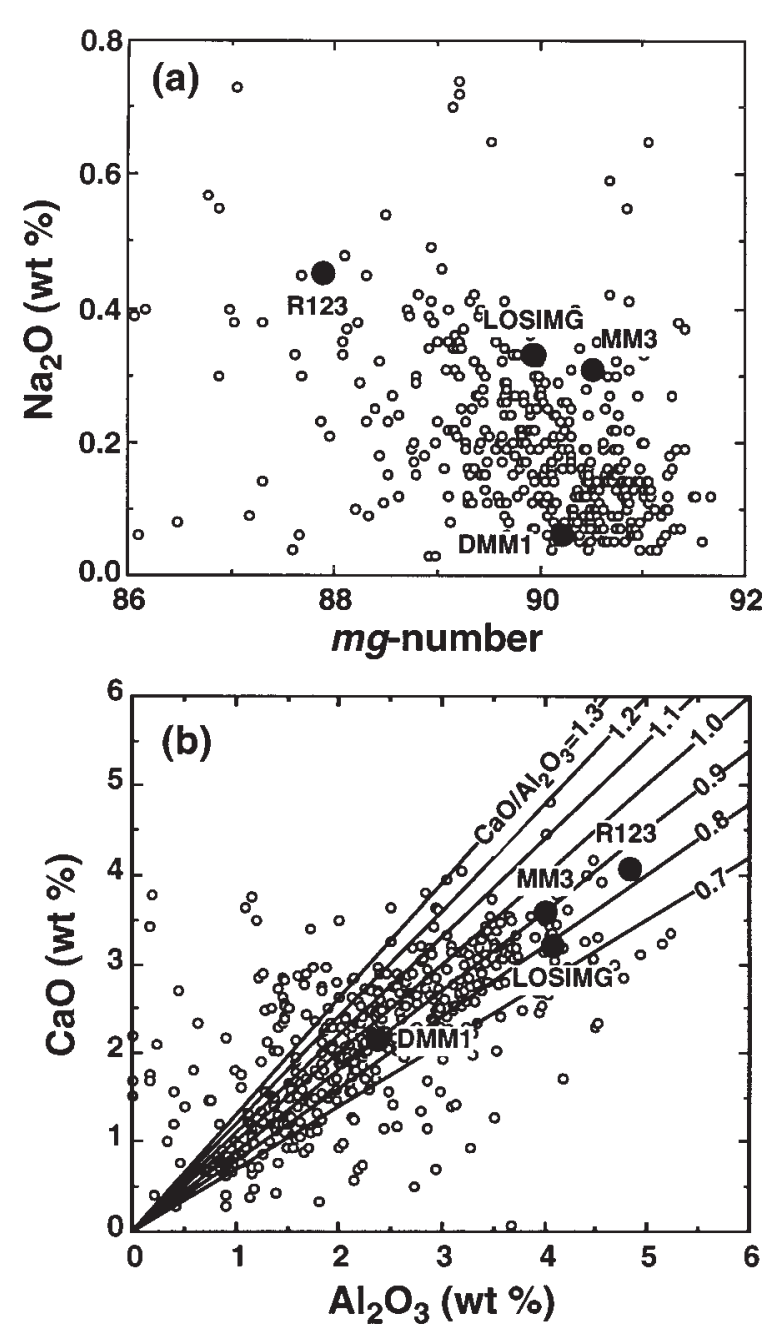

Fig. 5. Labeled, filled circles show the compositions of the four peridotitic compositions used in calculations and discussed in the text (see Table 1 for full compositions). (a) $m g$-number $[=$ molar $\mathrm{MgO} /$ $\left.\left(\mathrm{MgO}+\mathrm{FeO}^{*}\right)\right]$ vs $\mathrm{Na}_{2} \mathrm{O}$ and (b) $\mathrm{Al}_{2} \mathrm{O}_{3}$ vs $\mathrm{CaO}$. Small open circles are peridotite compositions from the compilation of Herzberg et al. (1988).

depending on the extent of this increase in melt fraction related to source composition, the $\mathrm{Na}$ contents of partial melts of Na-rich peridotites may actually be lower than those of Na-poor peridotites at the same pressure and temperature, and it can be a difficult task to determine to what extent variations in $\mathrm{Na}$ in basalts reflect variable source composition as opposed to variations in the degree of melting (or in melting processes) of a single source.

The extents of melting achieved by peridotites differing in composition will also depend on the distribution of compositionally distinct sources in the mantle. For example, if two isolated regions of solid mantle with different compositions (but both initially at the same temperature and pressure) were to melt partially in response to reversible adiabatic (i.e. isentropic) upwelling, each would have approximately the same entropy, but at any depth the region with the more fertile composition would be melted to a greater extent and hence be at a lower temperature than the region with the less fertile composition. On the other hand, if the same two upwelling solid sources (initially at the same temperature and pressure) were in contact and sufficiently small in dimension $(<5 \mathrm{~km}$, Sleep, 1984), they would approach thermal equilibrium with each other as upwelling and melting proceed. It should be noted that this process would not be isentropic, as the thermal equilibration step is not reversible. Under such circumstances, the compositionally distinct regions would have nearly the same temperature at each pressure, leading to greater contrasts between the degrees of melting of the two sources, as the less fertile, hotter peridotite would heat the more fertile, colder peridotite, further inhibiting melting in the former and enhancing melting in the latter (Hirschmann \& Stolper, 1996). Thus, the relationship between source composition and the degree of melting (and composition of partial melt) depends on the length scale of mantle heterogeneity.

Characterization of the effects of regional variations in source composition on the average composition of partial melts formed by upwelling is best left to a full treatment of adiabatic melting (Asimow et al., 1999). However, for small-scale heterogeneity, it is useful to compare the compositions of melts formed from disparate peridotite compositions at the same temperature and pressure. MELTS calculations of partial melt compositions for the four peridotite compositions we have considered show that constant temperature trends on a plot of $\mathrm{Na}_{2} \mathrm{O}$ vs $F$ can have either positive or negative slopes, depending on the actual compositions being compared and on the temperature (Fig. 6a). A negative $\mathrm{Na}_{2} \mathrm{O}$ vs $F$ slope signifies that the Na-enriched sources are predicted to melt to a sufficiently greater extent that they actually produce liquids with lower $\mathrm{Na}_{2} \mathrm{O}$ contents. For example, the slope in Fig. 6a is negative at $1370^{\circ} \mathrm{C}$ for the MM3, LOSIMG, and R123 compositions. However, this effect is not universal: at all temperatures, $\mathrm{Na}_{2} \mathrm{O}$ and $F$ are both calculated to increase from the depleted DMM1 composition to the fertile MM3 composition, and at 1400 and $1430^{\circ} \mathrm{C}$ the calculated trends with increasing $F$ from fertile to enriched peridotites are of roughly constant $\mathrm{Na}_{2} \mathrm{O}$. Nevertheless, it is clear that interpretation of $\mathrm{Na}$ contents of basalts is not likely to be straightforward if source heterogeneity is significant. The difference between DMM1 and those compositions that display a negative slope at low temperature in Fig. 6a may be related in part to the compositional variations that accompany the variations in source $\mathrm{Na}_{2} \mathrm{O}$ concentration. For example, MM3 and LOSIMG have five 
times more $\mathrm{Na}_{2} \mathrm{O}$ than DMM1 and $2 / 3$ the $\mathrm{Na}_{2} \mathrm{O}$ of $\mathrm{R} 123$ (Table 1). But $\mathrm{Na}_{2} \mathrm{O}$ is not the only compositional factor affecting productivity. Relative differences in other such compositional factors (e.g. mg-number, modal cpx contents) between these compositions are not as extreme as for $\mathrm{Na}_{2} \mathrm{O}$, so at any temperature, the difference in extent of melting is not sufficient to compensate for the difference in source $\mathrm{Na}_{2} \mathrm{O}$ for DMM1 vs MM3 or LOSIMG, but is for MM3 or LOSIMG vs R123.

Experimental studies of peridotite melting at $1 \mathrm{GPa}$ support the inferences from calculated $\mathrm{Na}_{2} \mathrm{O}$ vs $F$ trends (Fig. 6b). At $1250^{\circ} \mathrm{C}$, the compiled results show that there is a strong negative correlation between melt fraction and $\mathrm{Na}_{2} \mathrm{O}$ in the liquid. At 1300 and $1350^{\circ} \mathrm{C}$, the trends are less clear, perhaps because of large uncertainties associated with estimates of melt fractions at high melt fractions from analysis of incompatible elements, but at both temperatures there is little or no consistent variation in $\mathrm{Na}_{2} \mathrm{O}$ content as a function of $F$ for the melts of these peridotite compositions. These trends are similar to those calculated by MELTS for low vs high temperature and shown in Fig. 6a (although the temperature $-F$ relations of MELTS calculations are systematically offset; see Hirschmann et al., 1998b). The reason for the strong negative correlation between $\mathrm{Na}_{2} \mathrm{O}$ contents of liquids and the extent of melting at low temperature is that at low melt fraction, melt $\mathrm{Na}_{2} \mathrm{O}$ is affected more by the extent of melting than by the $\mathrm{Na}_{2} \mathrm{O}$ content of the source (i.e. Na contents of partial melts increase to very high values at low $F$ regardless of the $\mathrm{Na}$ content of the source). The key point is the somewhat surprising result that for regions of the mantle that are at constant temperature but compositionally heterogeneous on a small scale, basalts more enriched in alkalis (and other incompatible elements) can be derived from less alkalirich sources provided the overall extent of melting in the most depleted regions is small.

\section{Trends in $\mathrm{CaO}, \mathrm{Al}_{2} \mathrm{O}_{3}$, and $\mathrm{CaO} / \mathrm{Al}_{2} \mathrm{O}_{3}$ of partial melts of peridotite}

Variations in source composition can affect compositions of partial melts in unexpected ways. This is best illustrated by $\mathrm{CaO}$, the concentration of which in a partial melt is not a simple function of the $\mathrm{CaO}$ content of the source. Understanding the factors that influence the $\mathrm{CaO}$ contents of partial melts is necessary for quantitative interpretation of the $\mathrm{CaO} / \mathrm{Al}_{2} \mathrm{O}_{3}$ ratios of basalts, which are commonly taken as a robust indicator of the extent of partial melting in the source (Niu \& Batiza, 1991; Niu \& Hékinian, 1997). We shall see that although this ratio is indeed a monotonic function of the degree of melting of any given lherzolitic [i.e. (ol $+\mathrm{opx}+\mathrm{cpx})$-bearing] source so long as cpx remains in the residue, it is strongly
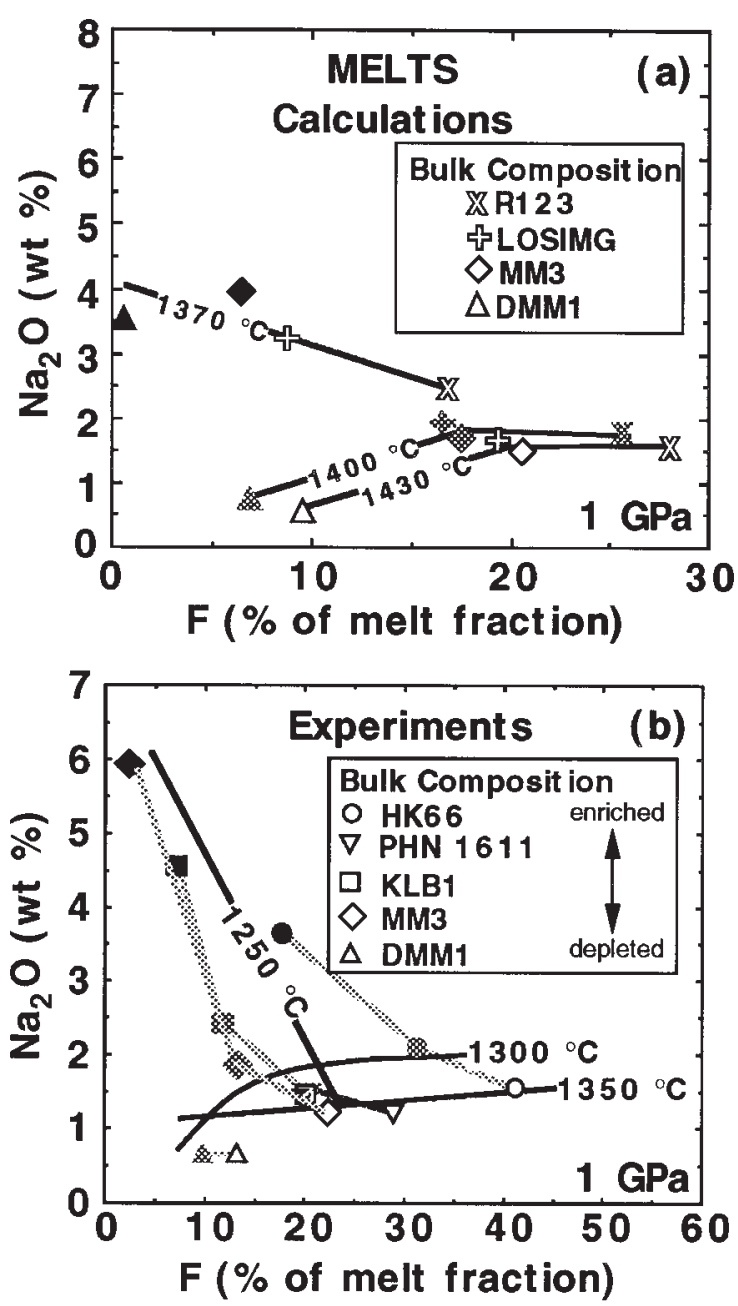

Fig. 6. (a) Calculated $\mathrm{Na}_{2} \mathrm{O}$ vs melt fraction in partial melts at $1 \mathrm{GPa}$ for the peridotite compositions illustrated in Fig. 5 and given in Table 1. Calculations are shown at $1370^{\circ} \mathrm{C}$ (filled symbols), $1400^{\circ} \mathrm{C}$ (shaded symbols) and $1430^{\circ} \mathrm{C}$ (open symbols); approximate isotherms connecting the four compositions are also shown (bold lines) at each temperature. The isothermal trends for these compositions have both positive and negative slopes, suggesting that peridotites that are more fertile (in the sense that they melt more for a given $T$ and $P$ ) can, depending on temperature and the details of the compositional variations in the sources, produce melts with greater or lesser amounts of $\mathrm{Na}_{2} \mathrm{O}$ than melts of more depleted sources at the same conditions. (b) Experimental data at $1 \mathrm{GPa}$ for several peridotite compositions: MM3 (Baker \& Stolper, 1994; Baker et al., 1995; Hirschmann et al., 1998a), HK66 and KLB-1 (Hirose \& Kushiro, 1993), PHN1611 (Kushiro, 1996), and DMM1 (Wasylenki et al., 1996) at $1250^{\circ} \mathrm{C}$ (filled symbols), $1300^{\circ} \mathrm{C}$ (shaded symbols) and $1350^{\circ} \mathrm{C}$ (open symbols). Datum for DMM1 at $1300^{\circ} \mathrm{C}$ is interpolated between experiments at $1290^{\circ} \mathrm{C}$ and $1310^{\circ} \mathrm{C}$. Light gray lines connect experiments from common bulk compositions. As in (a), the negative slope at $1250^{\circ} \mathrm{C}$, contrasting with those at higher temperatures, indicates that at lower temperatures, more fertile (i.e. Na-rich) peridotites such as HK-66 $\left(0.66\right.$ wt $\left.\% \mathrm{Na}_{2} \mathrm{O}\right)$ can produce partial melts with distinctly lower $\mathrm{Na}_{2} \mathrm{O}$ contents that those of more depleted peridotites, owing to the dilution of $\mathrm{Na}_{2} \mathrm{O}$ that occurs at the higher extent of melting; at higher temperatures, the effect of bulk composition is more important than the effect of extent of melting, and the relative $\mathrm{Na}_{2} \mathrm{O}$ contents of the partial melts track those of their sources. 
affected by variations in source composition and thus could be less useful as a monitor of degree of melting than has been thought previously.

MELTS calculations of the $\mathrm{CaO}$ and $\mathrm{Al}_{2} \mathrm{O}_{3}$ contents of partial melts of a range of peridotite source compositions as a function of melt fraction at $1 \mathrm{GPa}$ are shown in Fig. 7a. For any given peridotite composition, the $\mathrm{CaO}$ content of the partial melt is predicted to reach a maximum at the point of cpx exhaustion (as also shown by partial melting experiments; Baker \& Stolper, 1994; Kushiro, 1996). For the bulk compositions examined (Table 1 and Fig. 5), the predicted maximum concentration of $\mathrm{CaO}$ varies little between different bulk compositions but occurs at markedly different extents of melting, owing to variations in initial cpx abundances calculated for peridotites with these compositions. This leads to the somewhat paradoxical (and to our knowledge, previously unknown) prediction that at any given small degree of melting, the $\mathrm{CaO}$ concentrations of partial melts of bulk compositions with lower $\mathrm{CaO}$ contents (and hence lower modal cpx) tend to be higher than those of bulk compositions having higher concentrations of $\mathrm{CaO}$ (e.g. compare the predicted $\mathrm{CaO}$ contents of partial melts of DMM1, MM3 and LOSIMG, and R123 at 5\% melting in Fig. 7a). This prediction from MELTS is borne out by the differences in experimentally determined liquid compositions from experiments on the fertile MM3 and depleted DMM1 peridotite compositions (Wasylenki et al., 1996).

The surprising behavior of $\mathrm{CaO}$ occurs because temperature and other aspects of melt composition, not bulk peridotite $\mathrm{CaO}$ or melt fraction, are the most important variables affecting the $\mathrm{CaO}$ concentrations of $(\mathrm{ol}+\mathrm{opx}+\mathrm{cpx})$-saturated liquids. This can be seen by examination of the reaction

$$
\begin{aligned}
& \mathrm{CaMgSi}_{2} \mathrm{O}_{6} \rightleftharpoons \mathrm{CaSiO}_{3}+\frac{1}{2} \mathrm{Mg}_{2} \mathrm{Si}_{2} \mathrm{O}_{6} \\
& \text { cpx liquid opx }
\end{aligned}
$$

such that the activity and mole fraction of the $\mathrm{CaSiO}_{3}$ component in the liquid [which are in turn simply and directly related to those of $\mathrm{CaO}$ for an (ol $+\mathrm{opx})$ saturated melt] are given by

$$
\begin{gathered}
a_{\mathrm{CaSiO}_{3}}^{\text {liquid }}=\frac{a_{\mathrm{diop}}^{\mathrm{cpx}}}{a_{\mathrm{en}}^{\text {opx }} \text { 0.5 }} \exp \left(\frac{-\Delta G_{\text {react 2 }}^{0}}{\mathrm{RT}}\right) \\
X_{\mathrm{CaSiO}_{3}}^{\text {liquid }}=\frac{a_{\mathrm{CaSiO}_{3}}^{\text {liquid }}}{\gamma_{\mathrm{CaSiO}_{3}}^{\text {liquid }}}
\end{gathered}
$$

where $\Delta G_{\text {react2 }}^{0}$ is the free energy of reaction (2), $R$ is the gas constant, and $\mathcal{T}$ is in kelvins. $\mathrm{CaSiO}_{3}$ is used as the
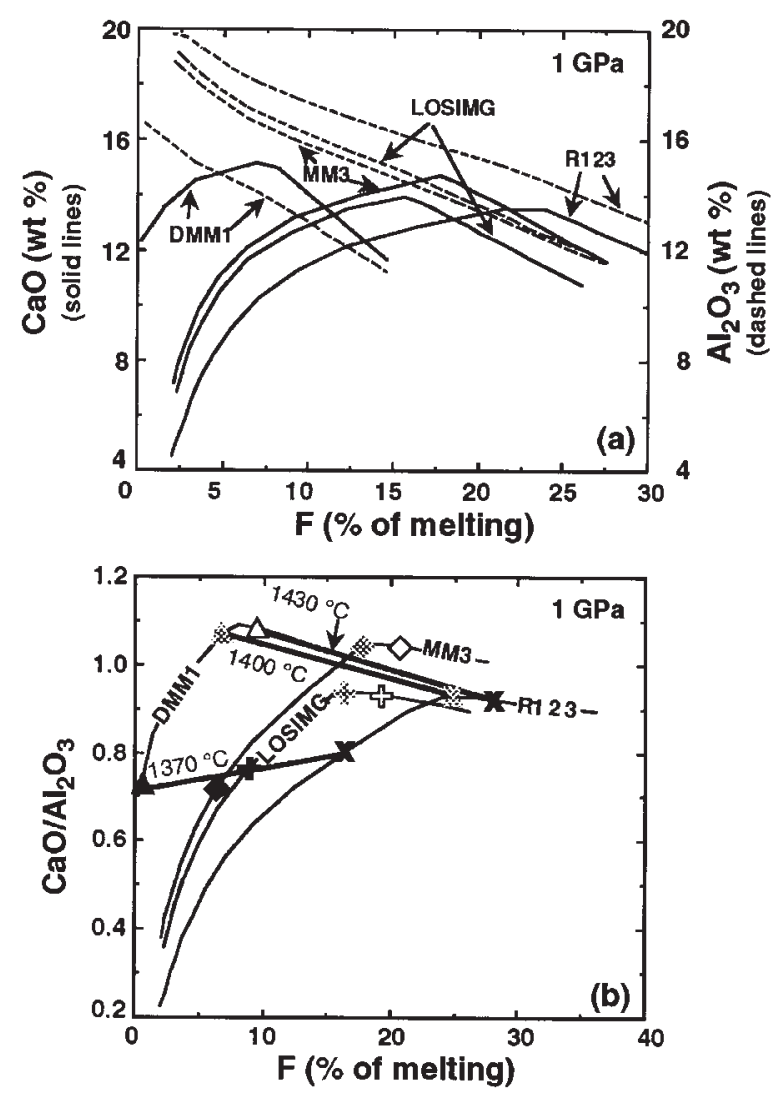

Fig. 7. Calculated (a) $\mathrm{CaO}$ and $\mathrm{Al}_{2} \mathrm{O}_{3}$, and (b) $\mathrm{CaO} / \mathrm{Al}_{2} \mathrm{O}_{3}$ for partial melts of the four peridotite compositions displayed in Fig. 5. Symbols for bulk compositions are the same as in Fig. 6. Approximate constant temperature trends ('isotherms') connecting the four compositions are also shown (bold lines) at $1370^{\circ} \mathrm{C}$ (filled symbols), $1400^{\circ} \mathrm{C}$ (shaded symbols) and $1430^{\circ} \mathrm{C}$ (open symbols). At any given melt fraction, relatively enriched bulk compositions (richer in $\mathrm{Al}_{2} \mathrm{O}_{3}, \mathrm{CaO}$ and $\mathrm{Na}_{2} \mathrm{O}$, and with lower solidus temperatures) yield partial melts that are richer in $\mathrm{Al}_{2} \mathrm{O}_{3}$ but poorer in $\mathrm{CaO}$. As a result, the $\mathrm{CaO} / \mathrm{Al}_{2} \mathrm{O}_{3}$ ratios of partial melts of depleted peridotites are much greater than those of melts of enriched peridotites at the same melt fraction. It should be noted that the low-temperature trend in (b) has a positive slope and the high-temperature trends have negative slopes.

liquid component in reaction (2) because it is the calcic liquid component in the MELTS liquid model (Ghiorso \& Sack, 1995).

For partial melts of the MM3 peridotite composition at $1 \mathrm{GPa}$ (Hirschmann et al., 1998b), MELTS-calculated values of $X_{\mathrm{CaSiO}_{3}}^{\mathrm{liquid}}, a_{\mathrm{CaSiO}_{3}}^{\text {liquid }}$, and $\gamma_{\mathrm{CaSiO}_{3}}^{\text {liquid }}$ are shown in Fig. 8. Comparison of Fig. 8a, $8 \mathrm{~b}$ and $8 \mathrm{c}$ shows that the significant decreases in $X_{\mathrm{CaSiO}_{3}}^{\mathrm{liquid}}$ as the solidus is approached reflect both decreasing $a_{\mathrm{CaSiO}_{3}}^{\text {liquid }}$ and increasing $\gamma_{\mathrm{CaSiO}_{3}}^{\text {liquid }}$. Inspection of equation (3) shows that variations in $a_{\mathrm{CaSiO}_{3}}^{\text {liquid }}$ are caused mainly by temperature, as changes in $a_{\mathrm{en}}^{\mathrm{opx}}$ and $a_{\text {diop }}^{\text {cpx }}$ over this interval are small and in any case would tend (all other things being equal) to produce changes in the activity of $\mathrm{CaSiO}_{3}$ opposite to what is shown in Fig. $8 \mathrm{~b}$ (i.e. $a_{\mathrm{diop}}^{\mathrm{cpx}}$ is higher and $a_{\mathrm{en}}^{\mathrm{opx}}$ is lower near 


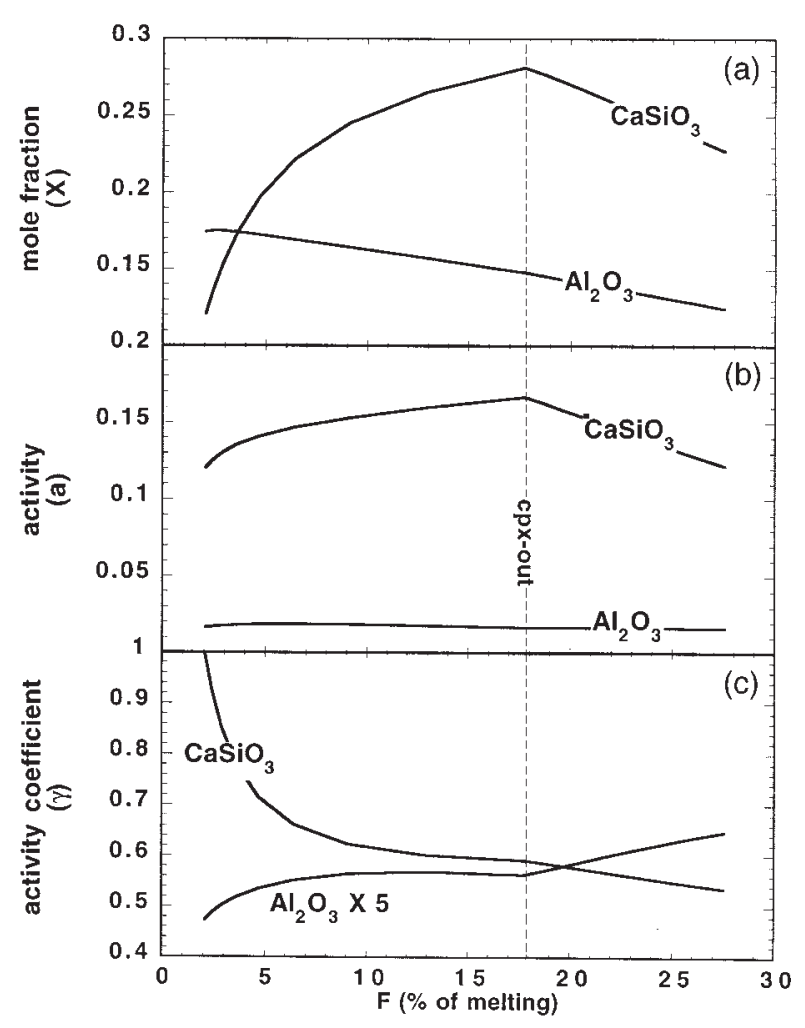

Fig. 8. Calculated percent melting $(F)$ vs (a) mole fraction $(X)$, (b) activity (a) and (c) activity coefficient $(\gamma)$ of $\mathrm{CaSiO}_{3}$ and $\mathrm{Al}_{2} \mathrm{O}_{3}$ components in partial melts of MM3 peridotite at $1 \mathrm{GPa}$. Calculated liquids in wt \% oxides are given in the Appendix of Hirschmann et al. (1998b). $X_{\mathrm{CaSiO}_{3}}^{\text {liquid }}$ increases steadily and significantly from the solidus up to exhaustion of cpx, whereas $X_{\mathrm{Al}_{2} \mathrm{O}_{3}}^{\mathrm{liq}}$ decreases steadily. It should be noted that $\gamma_{\mathrm{Al}_{2} \mathrm{O}_{3}}^{\mathrm{liq}}$ in (c) is multiplied by a factor of five.

the solidus because cpx is more $\mathrm{Ca}$ rich and opx is less enstatite rich). This temperature effect for $\mathrm{CaO}$ is analogous to the behavior of other oxide components for which concentrations are controlled by temperaturedependent positions of mineral cotectics. Thus the temperature dependence of the $\mathrm{CaO}$ contents of liquids in equilibrium with lherzolite residua is conceptually similar to those observed for $\mathrm{FeO}$ and $\mathrm{MgO}$ in liquids, both of which also decrease as melt fraction decreases for partial melting of peridotite (e.g. Langmuir et al., 1992).

Although temperature plays a significant role, the significant calculated decreases in $\mathrm{CaO}$ with decreasing $F$ (i.e. $F<5-8 \%$ ) largely reflect the influence of the even

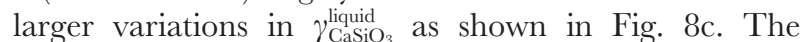
correspondingly large near-solidus changes in $\mathrm{FeO}$ and $\mathrm{MgO}$ found experimentally (Baker et al., 1995) and calculated with MELTS (Hirschmann et al., 1998b) are also likely to be the result primarily of variations in liquid activity coefficients (though detailed discussion of $\mathrm{FeO}$ and $\mathrm{MgO}$ variations in this context is beyond the scope of this paper). It is likely that the most important factor in the substantial near-solidus variation in $\gamma_{\mathrm{CaSiO}_{3}}^{\text {liquid }}$ is (as with the activity of silica discussed above) the large nearsolidus increase in the $\mathrm{Na}_{2} \mathrm{O}$ contents of the partial melts of fertile peridotite (especially relative to $\mathrm{Al}_{2} \mathrm{O}_{3}$; e.g. Baker et al., 1995; Hirschmann et al., 1998b). Specifically, we think it likely that increases in $\mathrm{Na} / \mathrm{Al}$ of the liquid as the solidus is approached lead to decreases in the proportion of $\mathrm{Ca}$ ions associated with aluminate species because $\mathrm{Al}$ associates more strongly with $\mathrm{Na}$ (George \& Stebbins, 1996), resulting in an increase in the fraction of Ca ions associated with silica. This in turn causes an increase in the activity coefficients of Ca-silicate species. This explanation may, however, be oversimplified, as there are likely to be other contributing factors because melt composition is changing rapidly and in many ways as the solidus is approached.

The behavior of $\mathrm{Al}_{2} \mathrm{O}_{3}$ in calculated peridotite-saturated liquids differs from that of $\mathrm{CaO} . \mathrm{Al}_{2} \mathrm{O}_{3}$ concentration in the melt decreases continuously with increasing $F$ for a given bulk composition. When different peridotite compositions are compared at a given $F$, the $\mathrm{Al}_{2} \mathrm{O}_{3}$ content of the melt varies monotonically with source $\mathrm{Al}_{2} \mathrm{O}_{3}$ (Fig. 7a) and appears not to be strongly affected by the $\mathrm{Al}_{2} \mathrm{O}_{3}$ concentration of the peridotite source (Fig. 5b); i.e. R123 has two times more $\mathrm{Al}_{2} \mathrm{O}_{3}$ than DMM1 (Table 1), but at any given melt fraction, the predicted $\mathrm{Al}_{2} \mathrm{O}_{3}$ contents of partial melts of these sources differ only by a factor of about $1 \cdot 3$. This behavior can be understood by examination of the following reaction, analogous to that examined above for $\mathrm{CaO}$, which effectively buffers the alumina activity of the melt:

$$
\begin{aligned}
& \mathrm{MgAl}_{2} \mathrm{O}_{4}+\frac{1}{2} \mathrm{Mg}_{2} \mathrm{Si}_{2} \mathrm{O}_{6} \rightleftharpoons \mathrm{Al}_{2} \mathrm{O}_{3}+\mathrm{Mg}_{2} \mathrm{SiO}_{4} \\
& \text { spinel opx liq ol }
\end{aligned}
$$

such that

$$
\begin{aligned}
& a_{\mathrm{Al}_{2} \mathrm{O}_{3}}^{\mathrm{liq}}=\frac{a_{\mathrm{MgAl}_{2} \mathrm{O}_{4}}^{\mathrm{sp}} a_{\mathrm{en}}^{\mathrm{opx}}}{a_{\mathrm{fo}}^{\mathrm{ol}}} \exp \left(\frac{-\Delta G_{\text {react } 5}^{0}}{\mathrm{RT}}\right) \\
& X_{\mathrm{Al}_{2} \mathrm{O}_{3}}^{\mathrm{liq}}=\frac{a_{\mathrm{Al}_{2} \mathrm{O}_{3}}}{\gamma_{\mathrm{Al}_{2} \mathrm{O}_{3}}^{\mathrm{liq}}} .
\end{aligned}
$$

As illustrated by Fig. 8, $X_{\mathrm{Al}_{2} \mathrm{O}_{3}}^{\mathrm{liq}}$ increases as the solidus is approached because, although $a_{\mathrm{Al}_{2} \mathrm{O}_{3}}^{\text {liq }}$ is nearly constant, $\gamma_{\mathrm{Al}_{2} \mathrm{O}_{3}}^{\text {liq }}$ decreases steadily. The nearly constant activity comes from the approximately cancelling effects of temperature (which tend to lead to a decrease in $a_{\mathrm{Al}_{2} \mathrm{O}_{3}}^{\text {li with }}$ decreasing temperature, just as for $a_{\mathrm{CaSiO}_{3}}^{\text {liquid }}$ ) and an increase

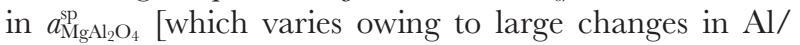
$(\mathrm{Al}+\mathrm{Cr})$ in the spinel coexisting with these liquids; for example, $\mathrm{Al} /(\mathrm{Al}+\mathrm{Cr})$ in the calculated spinel at $18 \%$ 
melting is $0 \cdot 438$, but this value increases to 0.591 at $2 \%$ melting; see the Appendix of Hirschmann et al. (1998b)].

It should be noted that the steady decrease in $\gamma_{\mathrm{Al}_{2} \mathrm{O}_{3}}^{\mathrm{lig}}$ with decreasing melt fraction contrasts with the increase calculated for $\gamma_{\mathrm{CaSiO}_{3}}^{\text {liquid }}$ (Fig 8c). Though we have not analyzed the cause of this trend in detail, some of it again probably reflects increases in the $\mathrm{Na}_{2} \mathrm{O}$ concentration of the liquid. For example, Hirschmann et al. (1998a) suggested that increasing $\mathrm{Na}$ relative to divalent cations ( $\mathrm{Ca}, \mathrm{Mg}, \mathrm{Fe}$ ), as occurs as the solidus is approached, leads to greater $\mathrm{Al}$ avoidance in partial melts of peridotite. This hypothesis is consistent with spectroscopic observations of simple glasses (Oestrike et al., 1987; Merzbacher \& White, 1991). Al avoidance would in turn

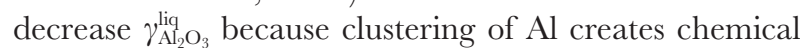
environments for $\mathrm{Al}$ ions that are more like that in the standard state (i.e. pure $\mathrm{Al}_{2} \mathrm{O}_{3}$ liquid).

The preceding analysis shows that cpx saturation in lherzolite-saturated liquids requires less $\mathrm{CaO}$ when the temperature is low and when liquids are rich in $\mathrm{Na}_{2} \mathrm{O}$. Although not our main point here, this provides an explanation for what Falloon et al. (1996, 1997) have suggested are anomalously low normative diopside contents of near-solidus partial melts of fertile MM3 peridotite determined by experiments (Baker et al., 1995; Hirschmann et al., 1998a). Moreover, $\mathrm{Al}_{2} \mathrm{O}_{3}$ contents of lherzolite-saturated liquids are greatest when spinels are aluminous and liquids are enriched in $\mathrm{Na}_{2} \mathrm{O}$. Because depleted lherzolites achieve any given extent of melting at higher temperature and with lower $\mathrm{Na}_{2} \mathrm{O}$ contents in the liquids than more fertile peridotites (Hirschmann et $a l ., 1998 b)$ and because the spinels in depleted peridotites have lower $\mathrm{Al} /(\mathrm{Cr}+\mathrm{Al})($ Dick et al., 1984), their partial melts are richer in $\mathrm{CaO}$ and poorer in $\mathrm{Al}_{2} \mathrm{O}_{3}$, leading to higher $\mathrm{CaO} / \mathrm{Al}_{2} \mathrm{O}_{3}$ at the same melt fraction. These are precisely the relations illustrated in Fig. 7: the calculated $\mathrm{CaO} / \mathrm{Al}_{2} \mathrm{O}_{3}$ ratio at any fixed melt fraction is highest for depleted (i.e. $\mathrm{CaO}$-poor) compositions and least for enriched (CaO-rich) compositions (as long as cpx is not exhausted from the residue) (Fig. 7).

It should be noted that $\mathrm{CaO} / \mathrm{Al}_{2} \mathrm{O}_{3}$ of the peridotite source also affects melt $\mathrm{CaO} / \mathrm{Al}_{2} \mathrm{O}_{3}$, but unless source $\mathrm{CaO} / \mathrm{Al}_{2} \mathrm{O}_{3}$ variations are very large, the relative enrichment or depletion (and therefore the $\mathrm{CaO}$ content) of the source appears to be a better predictor of the $\mathrm{CaO} / \mathrm{Al}_{2} \mathrm{O}_{3}$ of the partial melts at any given melt fraction. For example, MM3 and DMM1 have nearly identical $\mathrm{CaO} / \mathrm{Al}_{2} \mathrm{O}_{3}$ ratios but very different $\mathrm{CaO}$ (and more importantly, $\mathrm{Na}_{2} \mathrm{O}$ ), and $\mathrm{CaO} / \mathrm{Al}_{2} \mathrm{O}_{3}$ of their partial melts are dramatically different. A critical conclusion from this analysis is that the extent of melting of a peridotite source inferred from $\mathrm{CaO} / \mathrm{Al}_{2} \mathrm{O}_{3}$ is highly dependent on the source composition. For example, for $10 \%$ melting of the peridotite compositions shown in Fig. $7 \mathrm{~b}\left(\mathrm{CaO} / \mathrm{Al}_{2} \mathrm{O}_{3}\right.$ ranges from 0.79 to 0.90 in these source compositions), the liquid $\mathrm{CaO} / \mathrm{Al}_{2} \mathrm{O}_{3}$ ratio ranges from 0.65 to 1.08 and is not simply correlated with the ratio in the source. Similarly, a $\mathrm{CaO} / \mathrm{Al}_{2} \mathrm{O}_{3}$ ratio of $0 \cdot 8$, which is typical of many MORB (Niu \& Batiza, 1991), could correspond to extents of melting ranging from $<1 \%$ to $\sim 17 \%$, depending on the source composition.

$\mathrm{Niu} \&$ Hékinian (1997) argued that because $\mathrm{Na}_{2} \mathrm{O}$ is highly dependent on source composition, $\mathrm{CaO} / \mathrm{Al}_{2} \mathrm{O}_{3}$ is a superior indicator of extent of melting. However, as is clear from Fig. 7b, $\mathrm{CaO} / \mathrm{Al}_{2} \mathrm{O}_{3}$ is also highly dependent on source composition (and especially on $\mathrm{Na}_{2} \mathrm{O}$ content). Interestingly, Niu \& Hékinian (1997) noted a positive regional correlation between average fractionation-corrected $\mathrm{CaO} / \mathrm{Al}_{2} \mathrm{O}_{3}$ and extent of depletion in abyssal peridotites for the East Pacific Rise (EPR). Although they concluded that the average extent of melting is greater beneath those regions of the $\mathrm{EPR}$ with high $\mathrm{CaO} / \mathrm{Al}_{2} \mathrm{O}_{3}$ in basalt and more depleted peridotites, an alternative interpretation is that the observed correlation is simply the expected result of variations in source peridotite composition where regions in which peridotites are on average more depleted yield liquids with higher average $\mathrm{CaO} / \mathrm{Al}_{2} \mathrm{O}_{3}$.

As for $\mathrm{Na}_{2} \mathrm{O}$, more detailed exploration of the effect of regional heterogeneity on $\mathrm{CaO} / \mathrm{Al}_{2} \mathrm{O}_{3}$ of average basalt is best left for a full treatment of adiabatic melting, but for small-scale heterogeneity there are strong parallels between their effects on $\mathrm{Na}_{2} \mathrm{O}$ (see Fig. 6a) and on $\mathrm{CaO} / \mathrm{Al}_{2} \mathrm{O}_{3}$ (Fig. 7b). For example, for variable source compositions held at a constant, low temperature, MELTS predicts that variations in the extent of melting can have a greater influence on $\mathrm{CaO} / \mathrm{Al}_{2} \mathrm{O}_{3}$ in the melts than variations related to the initial degree of depletion of the source. Thus, the calculated melts produced from the four source compositions at $1370^{\circ} \mathrm{C}$ have a positive slope in Fig. 7b, suggesting that higher $\mathrm{CaO} / \mathrm{Al}_{2} \mathrm{O}_{3}$ liquids can come from more enriched sources (even though at a given $F$, enriched sources will produce melts with lower $\mathrm{CaO} / \mathrm{Al}_{2} \mathrm{O}_{3}$ ). However, at higher temperature, the composition of the source has a greater direct influence on partial melt compositions, and liquids produced from various sources at the same temperature have negative slopes, mimicking the behavior at constant $F$, where higher $\mathrm{CaO} / \mathrm{Al}_{2} \mathrm{O}_{3}$ liquids come from more depleted sources.

Basalts from a region in which the source peridotites are enriched will be richer in $\mathrm{Na}_{2} \mathrm{O}$ and have lower $\mathrm{CaO} / \mathrm{Al}_{2} \mathrm{O}_{3}$ than basalts produced by the same extent of melting from a 'normal', fertile peridotite source. In other words, they will mimic the characteristics of melts produced from a normal mantle region in which the average extent of melting is smaller. Because of this, it will be difficult to use covariations in $\mathrm{Na}_{2} \mathrm{O}$ and $\mathrm{CaO} /$ $\mathrm{Al}_{2} \mathrm{O}_{3}$ to deconvolve the effects of extent of melting from those of major element variations in the source, though 
correlations between average basalt compositions and crustal thickness provide additional constraints (Klein \& Langmuir, 1987; Langmuir et al., 1992). More accurate models of the range of melt compositions formed from polybaric melting are needed to provide a baseline for understanding what can be produced from homogeneous mantle of different potential temperatures. Also, more modeling of the effects of source heterogeneity on compositional variables is clearly needed. Ultimately, however, as is the case for incompatible trace elements, the best indicator of major element source heterogeneity may be a dissonance between the extent of melting as indicated by different measures (e.g. $\mathrm{Na}, \mathrm{Ca} / \mathrm{Al}$, etc.) assuming a homogeneous source. Returning to the example of the $\mathrm{EPR}$, fractionation-corrected values of $\mathrm{Na}_{2} \mathrm{O}$ and $\mathrm{CaO} /$ $\mathrm{Al}_{2} \mathrm{O}_{3}$ do not correlate (Niu \& Hékinian, 1997). As this is not readily understandable in the context of a homogeneous source, it may be an indication of largescale major element heterogeneity for this province. Local-scale mantle heterogeneity beneath the EPR has previously been inferred from other major and trace element variations (Langmuir et al., 1992).

\section{Trends in $\mathrm{K}_{2} \mathrm{O} / \mathrm{TiO}_{2}$ of partial melts of peridotite}

The ratio $\mathrm{K}_{2} \mathrm{O} / \mathrm{TiO}_{2}$ in $\mathrm{MORB}$ is often treated as an indicator of source region heterogeneity. Variations in $\mathrm{K}_{2} \mathrm{O} / \mathrm{TiO}_{2}$ among individual MORB samples have been interpreted as signifying local heterogeneity in MORB sources (Schilling et al., 1983; Hékinian et al., 1989; Sinton et al., 1991; Langmuir et al., 1992), and variations in $\mathrm{K}_{2} \mathrm{O} / \mathrm{TiO}_{2}$ of regionally averaged MORB compositions have been interpreted as signifying heterogeneity on a larger scale (Shen \& Forsyth, 1995). Although isotopic evidence confirms that $\mathrm{K}_{2} \mathrm{O} / \mathrm{TiO}_{2}$ of basalts varies with source composition at least in some cases (Schilling et al., 1983; Shen \& Forsyth, 1995), this does not exclude the possibility that variations in melting processes acting on a homogeneous source might also affect $\mathrm{K}_{2} \mathrm{O} / \mathrm{TiO}_{2}$. If $\mathrm{K}_{2} \mathrm{O} / \mathrm{TiO}_{2}$ can be affected by melting processes, then $\mathrm{K}_{2} \mathrm{O} / \mathrm{TiO}_{2}$ variations in individual MORBs or in regionally averaged MORB could in some cases reflect different melting or extraction histories, rather than or in addition to differences in the sources from which they were extracted.

Although $\mathrm{K}$ and $\mathrm{Ti}$ both behave incompatibly during peridotite partial melting, $\mathrm{K}_{2} \mathrm{O} / \mathrm{TiO}_{2}$ can vary in liquids produced by small degrees of melting because $\mathrm{Ti}$ is mildly incompatible in peridotite residua, with behavior similar to a heavy or middle REE, whereas $\mathrm{K}$ is strongly incompatible, similar to $\mathrm{Nb}$ or La (Sun \& McDonough, 1989). For example, if bulk $D_{\mathrm{Ti}}=0.06$ and $D_{\mathrm{K}}$ is effectively zero, as may be reasonably inferred from spinel peridotite partial melting experiments at moderate extents (8-20\%) of melting (Baker \& Stolper, 1994), then $\mathrm{K}_{2} \mathrm{O} /$ $\mathrm{TiO}_{2}$ in a batch melt formed from $5 \%$ melting will be $2 \cdot 1$ times that of the source, whereas a batch melt formed from $15 \%$ melting will have $\mathrm{K}_{2} \mathrm{O} / \mathrm{TiO}_{2}$ only $1 \cdot 3$ times that of the source (Fig. 9). This difference of a factor of 1.6 is potentially significant given that distinct source regions are commonly distinguished based on differences in $\mathrm{K}_{2} \mathrm{O} / \mathrm{TiO}_{2}$ ratios of about a factor of two (e.g. $\mathrm{K}_{2} \mathrm{O}$ / $\mathrm{TiO}_{2}$ in NMORB is typically $\sim 0 \cdot 04-0 \cdot 05$, and TMORB is defined as MORB with $\mathrm{K}_{2} \mathrm{O} / \mathrm{TiO}_{2}>0 \cdot 09-0 \cdot 14$; Hékinian et al., 1989; Reynolds et al., 1992). However, MELTS calculations and experiments show that variable $D_{\mathrm{Ti}}$, particularly at low melt fraction, could be responsible for even greater variations in $\mathrm{K}_{2} \mathrm{O} / \mathrm{TiO}_{2}$ in melts produced by partial melting of a homogeneous source. As illustrated in Fig. 9, both MELTS calculations and experiments suggest that at low melt fraction $(F<\sim 0 \cdot 05), \mathrm{K}_{2} \mathrm{O} / \mathrm{TiO}_{2}$ is significantly greater than that expected if partition coefficients were constant. As explained above, this is partly because the modal abundance of cpx, the mineral with the highest $D_{\mathrm{Ti}}$, increases as the solidus is approached (Niu \& Batiza, 1994). It also partly reflects the increase in $D_{\mathrm{Ti}}^{\mathrm{cpx} / \mathrm{melt}}$ near the solidus (Fig. 4b). Thus, experiments and calculations suggest that near-solidus (2-10\%) batch melts will have $\mathrm{K}_{2} \mathrm{O} / \mathrm{TiO}_{2}$ between 1.5 and 10 times their source values.

The trend shown in Fig. 9 suggests that variations in $\mathrm{K}_{2} \mathrm{O} / \mathrm{TiO}_{2}$ in individual MORB, commonly interpreted as indicative of distinct mantle sources, could instead reflect different degrees of melting of a homogeneous source [as has also been suggested by Kinzler (1997)]. Even at relatively high extents of melting $(8-15 \%), \mathrm{K}_{2} \mathrm{O} /$ $\mathrm{TiO}_{2}$ will show a gentle inverse correlation with extent of melting. Thus the trend of varying $\mathrm{K}_{2} \mathrm{O} / \mathrm{TiO}_{2}$ in regionally averaged basalts, interpreted as signifying source heterogeneity by Shen \& Forsyth (1995), could also partly reflect variations in the average extent of melting [as discussed in greater detail by Asimow et al. (1999)]. Also, because the $\mathrm{K}_{2} \mathrm{O} / \mathrm{TiO}_{2}$ expected for nearsolidus melts are extreme, $\mathrm{K}_{2} \mathrm{O} / \mathrm{TiO}_{2}$ can be affected by the efficiency of melt extraction and by the extraction process. For example, if small degree melts are preferentially extracted to specific parts of the mid-ocean ridge system, such as off-axis areas (Spiegelman, 1996), significant local variations in $\mathrm{K}_{2} \mathrm{O} / \mathrm{TiO}_{2}$ could result, with the on-axis lavas having low $\mathrm{K}_{2} \mathrm{O} / \mathrm{TiO}_{2}$ values and the off-axis regions having high values. In summary, $\mathrm{K}_{2} \mathrm{O} / \mathrm{TiO}_{2}$ (and by extension, other ratios of $\mathrm{K}$ to more compatible trace elements with high charges) in individual and regionally averaged basalt compositions may not always be robust indicators of source heterogeneity even when the total or average extent of melting is relatively high. 
\begin{tabular}{l|l|l|l} 
JOURNAL OF PETROLOGY & VOLUME 40 & NUMBER 2 & FEBRUARY 1999
\end{tabular}

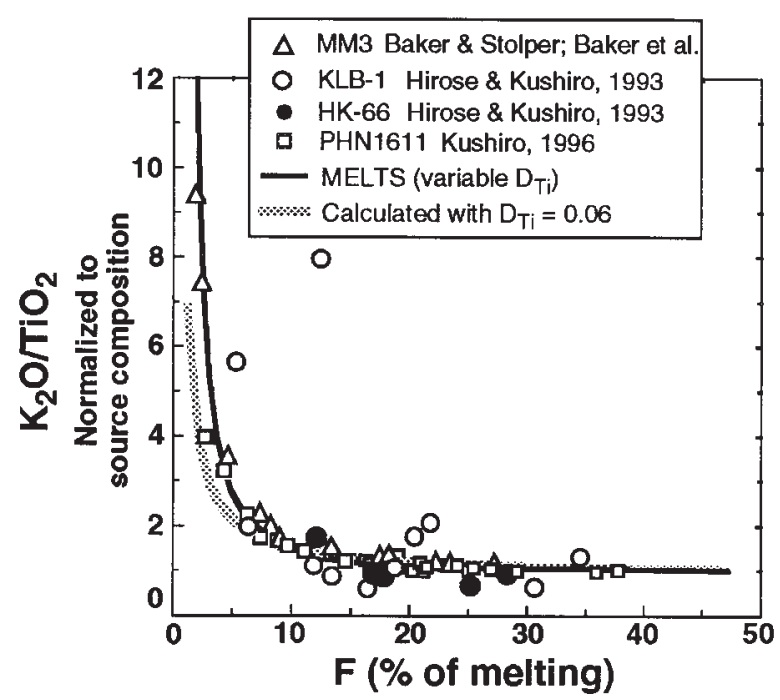

Fig. 9. Calculated and experimentally determined $\mathrm{K}_{2} \mathrm{O} / \mathrm{TiO}_{2}$ of partial melts of peridotite at $1 \mathrm{GPa}$ (normalized to the $\mathrm{K}_{2} \mathrm{O} / \mathrm{TiO}_{2}$ of the source composition) vs melt fraction. Partial melting experiments are for KLB1 and HK-66 (Hirose \& Kushiro, 1993); PHN1611 (Kushiro, 1996); and MM3 (Baker \& Stolper, 1994; Baker et al., 1995). The KLB-1 experimental data that plot significantly off the trend probably reflect inaccurate estimation of melt fraction, which was determined by assuming that $\mathrm{Na}_{2} \mathrm{O}$ is perfectly incompatible (Hirose \& Kushiro, 1993) The black curve is a MELTS calculation for MM3 peridotite; the gray curve is calculated with constant bulk distribution coefficients $\left(D_{\mathrm{K}}=\right.$ 0 and $\left.D_{\mathrm{Ti}}=0.06\right)$. It should be noted that the constant partition coefficient calculation systematically underpredicts $\mathrm{K}_{2} \mathrm{O} / \mathrm{TiO}_{2}$ at low melt fraction.

\section{Effects of source heterogeneity on melt $\mathrm{FeO}^{*}$}

One possible consequence of heterogeneity in MORB source regions is that it could affect the $\mathrm{FeO}^{*}$ content of partial melts, but the effect of source composition on melt $\mathrm{FeO}^{*}$ is contentious. Langmuir et al. (1992) inferred that the greater depth of initial melting and the higher $\mathrm{FeO}^{*}$ in an enriched source should in combination lead to higher $\mathrm{FeO}^{*}$ in melts from enriched peridotite. In contrast, Shen \& Forsyth (1995) observed an inverse correlation (in fractionation-corrected MORB compositions) between $\mathrm{FeO}^{*}$ and $\mathrm{K}_{2} \mathrm{O} / \mathrm{TiO}_{2}$, and inferred from this that more enriched sources produce melts with lower $\mathrm{FeO}^{*}$. Given that $\mathrm{K}_{2} \mathrm{O}$ concentrations in MORB are small, it is unlikely that the effect observed by Shen $\&$ Forsyth is the direct result on phase equilibria of $\mathrm{K}_{2} \mathrm{O}$ enrichment in the source, but other changes in source composition that tend to accompany $\mathrm{K}_{2} \mathrm{O}$ enrichment, such as enrichment in $\mathrm{Na}_{2} \mathrm{O}$, can clearly influence the compositions of low degree melts of peridotite (Baker et al., 1995; Hirschmann et al., 1998a, 1998b). However, examination of Fig. 10 shows that at $1 \mathrm{GPa}$ partial melts of peridotites with lower $m g$-numbers (R123 « LOSIMG $<$ DMM1 < MM3; see Fig. 5) have higher calculated

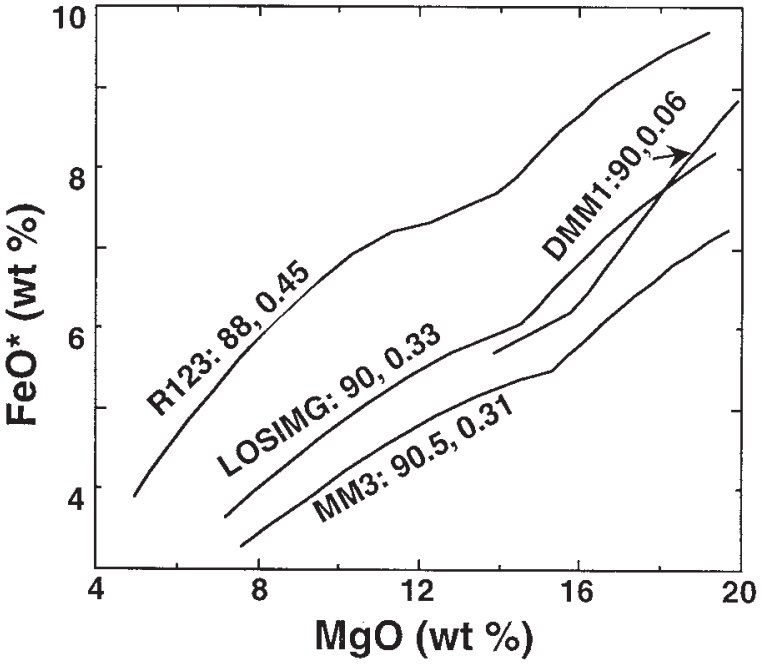

Fig. 10. Calculated $\mathrm{FeO}^{*}$ vs $\mathrm{MgO}$ at $1 \mathrm{GPa}$ for partial melts of the four peridotite compositions displayed in Fig. 5. Each curve is labeled with the name of the peridotite composition, followed by its $m g$-number and its bulk $\mathrm{Na}_{2} \mathrm{O}$ content. Bulk compositions with lower $m g$-numbers generally yield partial melts richer in $\mathrm{FeO}^{*}$ at any given $\mathrm{MgO}$, but bulk $\mathrm{Na}_{2} \mathrm{O}$ has little effect. An exception is that, at the highest $\mathrm{MgO}$ concentrations shown, calculated $\mathrm{FeO}^{*}$ of partial melts of DMM1 are slightly greater than those of LOSIMG, even though the bulk $m g$ number of LOSIMG is slightly less than that of DMM1. This occurs only at melt fractions higher than those needed to exhaust cpx (indicated by the kinks in the curves) and probably reflects the extreme alkali depletion in DMM1; it is not likely to be of general importance for typical melting regimes involving peridotites of moderately variable alkali content.

$\mathrm{FeO}^{*}$ contents at any given $\mathrm{MgO}$ content and that the $\mathrm{Na}_{2} \mathrm{O}$ concentration in the source has little effect.

If anything, we might actually expect peridotites with comparable $m g$-numbers but higher alkali contents to form partial melts with higher $\mathrm{FeO}^{*}$ at any given $\mathrm{MgO}$, the opposite of the trend suggested by Shen \& Forsyth (1995). This is because enrichment in alkalis causes partitioning of $\mathrm{Fe}$ and $\mathrm{Mg}$ between olivine and silicate liquid to become more extreme, as shown both by experiments and by MELTS calculations (Baker et al., 1995, 1996; Falloon et al., 1996; Draper \& Green, 1997; Robinson et al., 1998). Coupled with the overall trend of peridotite compositions to have lower $m g$-numbers (i.e. higher $\mathrm{FeO}^{*}$ ) when they are richer in alkalis (Fig. 5), we conclude that the empirical trend of averaged melts with higher $\mathrm{K}_{2} \mathrm{O} / \mathrm{TiO}_{2}$ having lower $\mathrm{MgO}$-normalized $\mathrm{FeO}^{*}$ noted by Shen \& Forsyth (1995) is not likely to be due to mantle heterogeneity unless increases in source $\mathrm{K}_{2} \mathrm{O}$ / $\mathrm{TiO}_{2}$ in mantle sources are coupled to increased $m g-$ number in MORB sources. Although mantle heterogeneities originating as metasomatized lithosphere (e.g. McKenzie \& O’Nions, 1983) might have this character, the results presented above suggest that a more likely explanation of the trend shown by Shen \& Forsyth (1995) 
is that $\mathrm{K}_{2} \mathrm{O} / \mathrm{TiO}_{2}$ is a poor indicator of mantle source composition, as it can depend strongly on the extent of melting in near-solidus melts (Fig. 9).

\section{GONGLUSIONS}

(1) For partial melting of fertile peridotite, MELTS predicts that near-solidus silica enrichment is pressure dependent. At $1 \mathrm{GPa}$, predicted near-solidus liquids have $\sim 5$ wt $\%$ more $\mathrm{SiO}_{2}$ than higher melt fractions, but at $3 \mathrm{GPa}$, the calculated magnitude of silica enrichment at $2 \%$ melting is $<1$ wt $\%$.

(2) For partial fusion of fertile peridotite, Ti (and, by analogy, other highly charged trace elements) is more compatible in cpx relative to silicate liquid near the solidus than at higher melt fractions. This behavior is partially caused by the increased $\mathrm{SiO}_{2}$ in near-solidus liquids, most notably at low and moderate pressures, and partially caused by changes in composition of cpx, as near-solidus cpx contains more $\mathrm{Na}^{+}$and $\mathrm{Al}^{3+}$, which stabilize highly charged cations that substitute into cpx by charge-coupled substitution. As a consequence of these changes in the cpx partition coefficient and the progressively higher abundance of residual cpx near the solidus of peridotite, predicted enrichments in $\mathrm{TiO}_{2}$ in low degree partial melts of fertile peridotite relative to their sources are less than those expected based on partition coefficients measured at high melt fractions, both at $1 \mathrm{GPa}$ and at higher pressures. Understanding the behavior of highly charged cations in near-solidus melts requires detailed characterization of their thermochemistry in near-solidus melts and their stability in nearsolidus crystalline phases.

(3) The effect of major element source heterogeneity on peridotite partial melts depends in part on the length scale of the heterogeneous domains. When the length scale is small, regions of different composition thermally equilibrate with each other and therefore are subjected to the same pressure-temperature trajectory during upwelling and melting. Under these circumstances, enriched regions of heterogeneous sources will melt to greater extents than they would if they melted isentropically (and depleted regions will melt to lesser extents). When melt fractions are small (e.g. $<\sim 10 \%)$ in the depleted regions of such heterogeneous, thermally equilibrated sources, this can lead to the unintuitive result that partial melts from the enriched regions produce melts with more 'depleted' major element characteristics (such as lower $\mathrm{Na}_{2} \mathrm{O}$ and higher $\mathrm{CaO} / \mathrm{Al}_{2} \mathrm{O}_{3}$ ) than partial melts from the depleted regions.

(4) $\mathrm{CaO} / \mathrm{Al}_{2} \mathrm{O}_{3}$ of partial melts of peridotite are sensitive to source composition. Depleted peridotites, although poorer in $\mathrm{CaO}$ than fertile or enriched peridotites, yield partial melts that at any fixed melt fraction are richer in $\mathrm{CaO}$ and higher in $\mathrm{CaO} / \mathrm{Al}_{2} \mathrm{O}_{3}$ than partial melts of fertile and enriched peridotites at the same melt fraction (for cpx-saturated melts). This reflects primarily the effects of alkalis and temperature on the activity coefficient of $\mathrm{CaO}$ in basic melts; for this reason, the $\mathrm{CaO} / \mathrm{Al}_{2} \mathrm{O}_{3}$ of the source (and the absolute concentration of $\mathrm{CaO}$, provided it is sufficient to stabilize cpx) is of secondary importance compared with source enrichment or depletion in controlling the $\mathrm{CaO} / \mathrm{Al}_{2} \mathrm{O}_{3}$ (and absolute $\mathrm{CaO}$ content) of the partial melts. For both $\mathrm{Na}_{2} \mathrm{O}$ and $\mathrm{CaO} / \mathrm{Al}_{2} \mathrm{O}_{3}$, the effects of source heterogeneity can lead to variations in the compositions of partial melts that mimic those of variations in extent of melting from a homogeneous source; as a consequence, distinguishing liquids produced by melting of a group of heterogeneous sources from those produced by variable degrees of melting of a homogeneous source using a limited number of chemical indicators can be problematic.

(5) $\mathrm{K}_{2} \mathrm{O} / \mathrm{TiO}_{2}$ is affected by the extent of melting even at melt fractions as high as $15 \%$, and therefore will in general be a poor indicator of source heterogeneity. Regional variations in $\mathrm{K}_{2} \mathrm{O} / \mathrm{TiO}_{2}$ ascribed to variations in source composition (Shen \& Forsyth, 1995) may also have been influenced by differences in extent of melting. Contrary to the inference by Shen \& Forsyth (1995), enriched peridotite sources are expected to yield partial melts with more $\mathrm{FeO}^{*}$ at any given $\mathrm{MgO}$ content than less enriched peridotite sources.

\section{AGKNOWLEDGEMENTS}

This work was supported by OCE-9711735 (M.M.H.), OCE-9529790 (M.S.G.), and EAR-9219899 and OCE9504517 (E.M.S.). We thank Paul Asimow, Mike Baker, and Laura Wasylenki for conversations and comments along the way, and Guatam Sen and Dave Draper for constructive reviews. This paper is Caltech Division of Geological and Planetary Sciences Contribution 8477.

\section{REFERENGES}

Asimow, P. D., Hirschmann, M. M. \& Stolper, E. M. (1999). Calculation of peridotite partial melting from thermodynamic models of minerals and melts. IV. Adiabatic decompression and the composition and mean properties of mid-ocean ridge basalts. Fournal of Petrology (in preparation).

Baker, M. B. \& Stolper, E. M. (1994). Determining the composition of high-pressure mantle melts using diamond aggregates. Geochimica et Cosmochimica Acta 58, 2811-2827.

Baker, M. B., Hirschmann, M. M., Ghiorso, M. S. \& Stolper, E. M. (1995). Compositions of near-solidus peridotite melts from experiments and thermodynamic calculations. Nature 375, 308-311.

Baker, M. B., Hirschmann, M. M., Wasylenki, L. E., Stolper, E. M. \& Ghiorso, M. S. (1996). Quest for low-degree mantle melts-Reply. Nature 381, 286. 
Blundy, J. D., Falloon, T. J., Wood, B. J. \& Dalton, J. A. (1995). Sodium partitioning between clinopyroxene and silicate melts. Fournal of Geophysical Research 100, 15501-15515.

Dick, H.J. B., Fischer, R. \& Bryan, W. B. (1984). Mineralogic variability of the uppermost mantle along mid-ocean ridges. Earth and Planetary Science Letters 69, 88-106.

Dickinson, J. E. \& Hess, P. C. (1985). Rutile solubility and titanium coordination in silicate melts. Geochimica et Cosmochimica Acta 49, 2289-2296.

Draper, D. \& Green, T. H. (1997). $P-T$ phase relations of silicic, alkaline, aluminous mantle-xenolith glasses under anhydrous and C-O-H fluid-saturated conditions. Foumal of Petrology 38, 1187-1224.

Dupré, B. \& Allègre, C. J. (1983). Pb-Sr isotope variation in Indian Ocean basalts and mixing phenomena. Nature 303, 142-146.

Falloon, T. J. \& Green, D. H. (1987). Anhydrous partial melting of MORB pyrolite and other peridotite compositions at 10 kbar: implications for the origin of primitive MORB glasses. Mineralogy and Petrology 37, 181-219.

Falloon, T. J., Green, D. H., O'Neill, H. S. C. \& Ballhaus, G. G. (1996). Quest for low-degree mantle melts. Nature 381, 285-286.

Falloon, T. J., Green, D. H., O’Neill, H. S. G. \& Hibberson, W. O. (1997). Experimental tests of low degree peridotite partial melt compositions: implications for the nature of anhydrous near-solidus peridotite melts at $1 \mathrm{GPa}$. Earth and Planetary Science Letters 152, 149-162.

Forsythe, L. M., Nielsen, R. L. \& Fisk, M. R. (1994). High-fieldstrength element partitioning between pyroxene and basaltic to dacitic magmas. Chemical Geology 117, 107-125.

Frey, F. A., Suen, C. J. \& Stockman, H. W. (1985). The Ronda hightemperature peridotite - geochemistry and petrogenesis. Geochimica et Cosmochimica Acta 49, 2469-2491.

Gallahan, W. E. \& Nielsen, R. L. (1992). The partitioning of Sc, Y, and the rare-earth elements between high-Ca pyroxene and natural mafic to intermediate lavas at 1 atmosphere. Geochimica et Cosmochimica Acta 56, 2387-2404.

George, A. M. \& Stebbins, J. F. (1996). Dynamics of Na in sodium aluminosilicate glasses and liquids. Physics and Chemistry of Minerals 23, 526-534.

Ghiorso, M. S. \& Sack, R. O. (1995). Chemical mass-transfer in magmatic processes. 4. A revised and internally consistent thermodynamic model for the interpolation and extrapolation of liquid-solid equilibria in magmatic systems at elevated temperatures and pressures. Contributions to Mineralogy and Petrology 119, 197-212.

Gudfinnsson, G. H. \& Presnall, D. C. (1996). Melting relations of model lherzolite in the systems $\mathrm{CaO}-\mathrm{MgO}-\mathrm{Al}_{2} \mathrm{O}_{3}-\mathrm{SiO}_{2}$ at $2 \cdot 4-3 \cdot 4$ $\mathrm{GPa}$ and the generation of komatiites. Fournal of Geophysical Research 101, 27701-27709.

Hart, S. R. \& Zindler, A. (1986). In search of a bulk-earth composition. Chemical Geology 57, 247-267.

Hékinian, R., Thompson, G. \& Bideau, D. (1989). Axial and offaxial heterogeneity of basaltic rocks from the East Pacific Rise at $12^{\circ} 35^{\prime} \mathrm{N}-12^{\circ} 51^{\prime} \mathrm{N}$ and $11^{\circ} 26^{\prime} \mathrm{N}-11^{\circ} 30^{\prime} \mathrm{N}$. Fournal of Geophysical Research 94, 17437-17463.

Herzberg, C., Feigenson, M., Skuba, C. \& Ohtani, E. (1988). Majorite fractionation recorded in the geochemistry of peridotites from South Africa. Nature 332, 823-826.

Hess, P. C. (1995). Thermodynamic mixing properties and the structure of silicate melts. Mineralogical Society of America, Reviews in Mineralogy 32, 145-189.

Hirose, K. \& Kushiro, I. (1993). Partial melting of dry peridotites at high pressures: determination of compositions of melts segregated from peridotite using aggregates of diamond. Earth and Planetary Science Letters 114, 477-489.
Hirschmann, M. M. \& Ghiorso, M. S. (1994). Activities of Ni-, Co-, and $\mathrm{Mn}$-silicate in magmatic liquids and applications to olivine/ liquid and to silicate/metal partitioning. Geochimica et Cosmochimica Acta 58, 4109-4126.

Hirschmann, M. M. \& Stolper, E. M. (1996). A possible role for garnet pyroxenite in the origin of the 'garnet signature' in MORB. Contributions to Mineralogy and Petrology 124, 185-208.

Hirschmann, M. M., Baker, M. B. \& Stolper, E. M. (1998a). The effect of alkalis on the silica content of mantle-derived magmas. Geochimica et Cosmochimica Acta 62, 883-902.

Hirschmann, M. M., Ghiorso, M. S., Asimow, P. D., Wasylenki, L. E. \& Stolper, E. M. (1998b). Calculation of peridotite partial melting from thermodynamic models of minerals and melts. I. Review of methods and comparison with experiments. Fournal of Petrology 39, 1091-1115.

Hirschmann, M. M., Asimow, P. D., Ghiorso, M. S. \& Stolper, E. M. (1999). Calculation of peridotite partial melting from thermodynamic models of minerals and melts. III. Controls on isobaric melt production and the effect of water on melt production. Fournal of Petrology (in press.)

Iwamori, H., McKenzie, D. \& Takahashi, E. (1995). Melt generation by isentropic mantle upwelling. Earth and Planetary Science Letters 134, 253-266.

Johnson, K. T. M., Dick, H. J. B. \& Shimizu, N. (1990). Melting in the oceanic upper mantle: an ion microprobe study of diopsides in abyssal peridotites. Foumal of Geophysical Research 95, 2661-2678.

Kelemen, P., Hirth, G., Shimizu, N., Spiegelman, M. \& Dick, H. J. B. (1997). A review of melt migration processes in the adiabatically upwelling mantle beneath oceanic spreading ridges. Philosophical Transactions of the Royal Society of London, Series A 355, 283-318.

Kinzler, R. J. (1997). Melting of mantle peridotite at pressures approaching the spinel to garnet transition: application to mid-ocean ridge basalt petrogenesis. Fournal of Geophysical Research 102, 853-874.

Kinzler, R. J. \& Grove, T. L. (1992a). Primary magmas of mid-ocean ridge basalts 1. Experiments and methods. Fournal of Geophysical Research 97, 6885-6906.

Kinzler, R. J. \& Grove, T. L. (1992b). Primary magmas of midocean ridge basalts. 2. Applications. Fournal of Geophysical Research 97, 6907-6926.

Klein, E. \& Langmuir, C. H. (1987). Global correlations of ocean ridge basalt chemistry with axial depth and crustal thickness. Fournal of Geophysical Research 92, 8089-8115.

Kushiro, I. (1975). On the nature of silicate melt and its significance in magma genesis: regularities in the shift of the liquidus boundaries involving olivine, pyroxene, and silica minerals. American fournal of Science 275, 411-431.

Kushiro, I. (1996). Partial melting of a fertile mantle peridotite at high pressure: an experimental study using aggregates of diamond. In: Basu, A. \& Hart, S. (eds) Earth Processes: Reading the Isotopic Clock. Geophysical Monograph, American Geophysical Union 95, 109-122.

Lange, R. A. \& Carmichael, I. S. E. (1987). Densities of $\mathrm{Na}_{2} \mathrm{O}-$ $\mathrm{K}_{2} \mathrm{O}-\mathrm{CaO}-\mathrm{MgO}-\mathrm{FeO}-\mathrm{Fe}_{2} \mathrm{O}_{3}-\mathrm{Al}_{2} \mathrm{O}_{3}-\mathrm{TiO}_{2}-\mathrm{SiO}_{2}$ liquids: new measurements and derived partial molar properties. Geochimica et Cosmochimica Acta 51, 2931-2946.

Lange, R. A. \& Navrotsky, A. (1993). Heat capacities of $\mathrm{TiO}_{2}$-bearing silicate liquids: evidence for anomalous changes in configurational entropy with temperature. Geochimica et Cosmochimica Acta 57, 30013011.

Langmuir, C. H., Klein, E. M. \& Plank, T. (1992). Petrological systematics of mid-ocean ridge basalts: constraints on melt generation beneath ocean ridges. In: Morgan, J. P., Blackman, D. K. \& Sinton, J. M. (eds) Mantle Flow and Melt Generation at Mid-Ocean Ridges. Geophysical Monograph, American Geophysical Union 71, 183-280. 
Longhi, J. (1995). Liquidus equilibria of some primary lunar and terrestrial melts in the garnet stability field. Geochimica et Cosmochimica Acta 59, 2375-2386.

Lundstrom, C. C., Shaw, H. F., Ryerson, F. J., Phinney, D. L., Gill, J. B. \& Williams, Q. (1994). Compositional controls on the partitioning of $\mathrm{U}, \mathrm{Th}, \mathrm{Ba}, \mathrm{Pb}, \mathrm{Sr}$ and $\mathrm{Zr}$ between clinopyroxene and haplobasaltic melts - implications for uranium series disequilibria in basalts. Earth and Planetary Science Letters 128, 407-423.

McKenzie, D. $(1985 a) .{ }^{230} \mathrm{Th}^{-238} \mathrm{U}$ disequilibrium and the melting process beneath ridge axes. Earth and Planetary Science Letters 72, 149-157.

McKenzie, D. (1985b). The extraction of magma from the crust and mantle. Earth and Planetary Science Letters 74, 81-91.

McKenzie, D. \& O’Nions, R. K. (1983). Mantle reservoirs and oceanic island basalts. Nature 301, 329-331.

Merzbacher, C. I. \& White, W. B. (1991). The structure of alkalineearth aluminosilicate glasses as determined by vibrational spectroscopy. Fournal of Non-Crystalline Solids 130, 18-34.

Mysen, B. \& Neuville, D. (1995). Effect of temperature and $\mathrm{TiO}_{2}$ content on the structure of $\mathrm{Na}_{2} \mathrm{Si}_{2} \mathrm{O}_{5}-\mathrm{Na}_{2} \mathrm{Ti}_{2} \mathrm{O}_{5}$ melts and glasses. Geochimica et Cosmochimica Acta 59, 325-342.

Natland, J. H. (1989). Partial melting of a lithologically heterogeneous mantle: inferences from crystallization histories of magnesian abyssal tholeiites from the Siqueiros Fracture Zone. In: Saunders, A. D. \& Norry, M. J. (eds) Magmatism in the Ocean Basins. Geological Society, London, Special Publication 42, 41-70.

Navrotsky, A. (1995). Energetics of silicate melts. Mineralogical Society of America, Reviewes in Mineralogy 32, 121-143.

Niu, Y. \& Hékinian, R. (1997). Spreading rate dependence of the extent of mantle melting beneath ocean ridges. Nature 385, 326-329.

Niu, Y. L. \& Batiza, R. (1991). An empirical method for calculating melt compositions produced beneath mid-ocean ridges: application to axis and off-axis (seamounts) melting. Fournal of Geophysical Research 96, 21753-21777.

Niu, Y. L. \& Batiza, R. L. (1994). Magmatic processes at a slowspreading ridge segment-26-degrees-S Mid-Atlantic ridge. Fournal of Geophysical Research 99, 19719-19740.

Oestrike, R., Yang, W. H., Kirkpatrick, R. J., Hervig, R. L., Navrotsky, A. \& Montez, B. (1987). High resolution ${ }^{27} \mathrm{Al}$ and ${ }^{29} \mathrm{Si} \mathrm{NMR}$ spectroscopy of framework aluminosilicate glasses. Geochimica et Cosmochimica Acta 51, 2199-2209.

Prinzhofer, A., Lewin, E. \& Allègre, C. J. (1989). Stochastic melting of the marble-cake mantle: evidence from local study of the EPR at $12^{\circ} 50^{\prime} \mathrm{N}$. Earth and Planetary Science Letters 92, 189-196.

Putirka, K., Johnson, M., Kinzler, R., Longhi, J. \& Walker, D. (1996). Thermobarometry of mafic igneous rocks based on clinopyroxeneliquid equilibria, 0-30 kbar. Contributions to Mineralogy and Petrology 123, 92-108.

Reynolds, J. R., Langmuir, C. H., Bender, J. F., Kastens, K. A. \& Ryan, W. B. F. (1992). Spatial and temporal variability in the geochemistry of basalts from the East Pacific Rise. Nature 359, 493-499.

Robinson, J. A. C., Wood, B. J. \& Blundy, J. D. (1998). The beginning of melting of fertile and depleted peridotite at $1.5 \mathrm{GPa}$. Earth and Planetary Science Letters 155, 97-111.

Roedder, E. (1951). The system $\mathrm{K}_{2} \mathrm{O}-\mathrm{MgO}-\mathrm{SiO}_{2}$. American fournal of Science 249, 81-130.

Ryerson, F. J. (1978). Implications of liquid-liquid distribution coefficients to mineral-liquid partitioning. Geochimica et Cosmochimica Acta 42, 921-932.

Ryerson, F. J. (1985). Oxide solution mechanisms in silicate meltssystematic variations in the activity-coefficient of $\mathrm{SiO}_{2}$. Geochimica et Cosmochimica Acta 49, 637-649.
Ryerson, F. J. \& Watson, E. B. (1987). Rutile saturation in magmas: implications for $\mathrm{Ti}-\mathrm{Nb}-\mathrm{Ta}$ depletion in island-arc basalts. Earth and Planetary Science Letters 86, 225-239.

Sack, R. O., Walker, D. \& Carmichael, I. S. E. (1987). Experimental petrology of alkalic lavas: constraints on cotectics of multiple saturation in natural basic liquids. Contributions to Mineralogy and Petrology 96, 1-23.

Salters, V. \& Longhi, J. (1996). Trace element partitioning during the initial stages of melting beneath a mid-ocean ridge. EOS Transactions, American Geophysical Union 77, 841.

Salters, V. J. M. \& Hart, S. R. (1989). The hafnium paradox and the role of garnet in the source of mid-oceanic-ridge basalts. Nature 342 , $420-422$.

Schairer, J. F., Yoder, H. \& Keene, A. G. (1954). The system $\mathrm{Na}_{2} \mathrm{O}-\mathrm{MgO}-\mathrm{SiO}_{2}$. Carnegie Institution of Washington Yearbook 53, 123-128.

Schilling, J. G., Zajac, M., Evans, R., Johnston, T., White, W., Devine, J. D. \& Kingsley, R. (1983). Petrologic and geochemical variations along the Mid-Atlantic Ridge from $29^{\circ} \mathrm{N}$ to $73^{\circ} \mathrm{N}$. American fournal of Science 283, 510-586.

Shen, Y. \& Forsyth, D. W. (1995). Geochemical constraints on initial and final depths of melting beneath mid-ocean ridges. Foumal of Geophysical Research 100, 2211-2237.

Sinton, J. M., Smaglik, S. M., Mahoney, J. J. \& MacDonald, K. C. (1991). Magmatic processes at superfast spreading midocean ridges - glass compositional variations along the East Pacific Rise 13 degrees-23 degrees S. Fournal of Geophysical Research 96, 6133-6155.

Sleep, N. H. (1984). Tapping of magmas from ubiquitous mantle heterogeneities; an alternative to mantle plumes? Fournal of Geophysical Research 89, 29-41.

Soulard, H. \& Wood, B. J. (1994). Lherzolite partial melting: closer to primary liquids. Mineralogical Magazine 58A, 866-867.

Spiegelman, M. (1996). Geochemical consequences of melt transport in 2-d - the sensitivity of trace-elements to mantle dynamics. Earth and Planetary Science Letters 139, 115-132.

Stille, P., Unruh, D. M. \& Tatsumoto, M. (1986). Pb, Sr, Nd and Hf isotopic constrains on the origin of Hawaiian basalts and evidence for a unique mantle source. Geochimica et Cosmochimica Acta 50, 2303-2319.

Stolper, E. (1980). A phase diagram for mid-ocean ridge basalts: preliminary results and implications for petrogenesis. Contributions to Mineralogy and Petrology 74, 13-27.

Sun, S. S. \& McDonough, W. F. (1989). Chemical and isotopic systematics of oceanic basalts: implications for mantle composition and processes. In: Saunders, A. D. \& Norry, M. J. (eds) Magmatism in the Ocean Basins. Geological Society, London, Special Publication 42, 313-346.

Walter, M. J. \& Presnall, D. C. (1994). Melting behavior of simplified lherzolite in the system $\mathrm{CaO}-\mathrm{MgO}-\mathrm{Al}_{2} \mathrm{O}_{3}-\mathrm{SiO}_{2}-\mathrm{Na}_{2} \mathrm{O}$ from 7 to 35 kbar. Fournal of Petrology 35, 329-359.

Walter, M. J., Sisson, T. W. \& Presnall, D. C. (1995). A mass proportion method for calculating melting reactions and application to melting of model upper-mantle lherzolite. Earth and Planetary Science Letters 135, 77-90.

Wasylenki, L. E., Baker, M. B., Hirschmann, M. M. \& Stolper, E. M. (1996). The effect of source depletion on equilibrium mantle melting. EOS Transactions, American Geophysical Union 77, 847.

Watson, E. B. (1976). Two liquid partition coefficients: experimental data and geochemical implications. Contributions to Mineralogy and Petrology 56, 119-134.

Zindler, A. \& Hart, S. (1986). Chemical geodynamics. Annual Review of Earth and Planetary Sciences 14, 493-571. 